\title{
Principios de obligatoriedad y discrecionalidad en el ejercicio de la acción penal
}

\author{
Manuel Rodríguez Vega*
}

\begin{abstract}
RESUMEN
En el artículo se intenta una novedosa-al menos para el medio nacional-aproximación a los siempre inasibles conceptos de obligatoriedad y discrecionalidad de la acción penal por parte del Ministerio Público, que permita al lector interesado distinguirlos adecuadamente entre sí e identificarlos en el examen de un sistema procesal específico. Igualmente se pretende diferenciar tales conceptos de otros relacionados, cuya confusión y superposición usualmente impide dialogar en el mismo registro a la doctrina. En ese orden, se revisa en los apartados II y III cómo la doctrina comparada y local aborda los principios de obligatoriedad y discrecionalidad de la acción penal, oportunidad y legalidad, así como otros a los que no obstante una distinta denominación suele atribuírsele el mismo contenido. En el apartado IV se brinda una rápida y panorámica mirada del ordenamiento adjetivo penal nacional respecto de la vigencia real y empírica de ambos conceptos.
\end{abstract}

Discrecionalidad - acción penal - Ministerio Público

\section{Principles of mandatory and discretionary prosecution}

\begin{abstract}
This article attempts a novel approach - at least for the Chilean doctrine - to the elusive concepts of obligation and discretion of criminal prosecution by the prosecutor office. This is carried out with the aim of enabling the interested reader to properly distinguish and individualize them when examining a specific procedural system. It also attempts to distinguish them from other related concepts, which usually overlap and confuse, thereby inbibiting dialogue about the doctrine. Sections II and III review how local and comparative doctrines address mandatory and discretionary prosecution and legality, as well as others that are different in name but not in content. Section IV gives a brief but panoramic look at the Chilean criminal system regarding the real and empirical validity of both concepts.
\end{abstract}

Discretionally - criminal proceedings- prosecutor office

* Abogado, Magíster en Derecho Penal, Profesor de Derecho Penal de la U. Católica Silva Henríquez, Santiago de Chile. Dirección: Avda. Pedro Montt 1606, edificio F, piso 9, Santiago, Chile. Correo electrónico: merodrig@uc.cl

Artículo recibido el 15 de marzo de 2013 y aceptado para su publicación por el Comité Editorial el 29 de mayo de 2013. 


\section{INTRODUCCIÓN}

$\mathrm{C}$

omún se ha vuelto en el foro nacional poner en duda la fuerza y contenido que el Ministerio Público (MP en adelante) le da a la acción penal que ejerce ante los tribunales competentes, cuestionándose el aprovechamiento de diversos vacíos e imprecisiones del legislador para no ejercer la acción penal, siendo esta procedente a la vista de la prueba reunida ${ }^{1}$, o para devaluar la pretensión punitiva contenida en sus requerimientos y acusaciones ${ }^{2}$, transformando esto último en una eficiente herramienta de negociación con el imputado y su defensa, al amparo de una regulación legal que vincula al juzgador en los procedimientos simplificados de resolución inmediata y abreviado a dichas peticiones y que le provee de escasas herramientas para evitarlo o remediarlo.

Para sentenciar si tales reparos tienen o no sustento, se hace menester en forma previa efectuar algunas precisiones conceptuales ajustadas a las particularidades del proceso penal, y a las complejidades del sistema de justicia penal que lo acoge, que nos den luces para adoptar una postura conciliadora, que no olvide los fines del proceso penal ni específicamente los de la sanción penal, pero tampoco las dificultades que enfrenta todo sistema de justicia penal para absorber y resolver en tiempo oportuno todas las investigaciones y procesos judiciales que soporta.

Con lo anterior en mente, en este trabajo intentaremos esencialmente acordar algunas definiciones básicas, pero trascendentales para el correcto examen de un sistema procesal, respecto de conceptos vinculados al problema teórico de la obligatoriedad de la acción penal ${ }^{3}$.

${ }^{1}$ Tales reparos se han presentado principalmente a raíz de la imposibilidad de la víctima-querellante de ejercer la acción penal mediante la acusación particular si previamente el MP ha omitido formalizar cargos contra el imputado-querellado. Al respecto, nuestro Tribunal Constitucional (TC en adelante) ha emitido diversos pronunciamientos, vgr. SSTC Rol N N $^{\circ} 15-07$ de 19.08.2008, Rol No 1337-09 de 20.8.2009, Rol No 1.467-2009 de 29.12.2009, Rol No 1341-2009 de 15.04.2010, Rol No 1380-2009 de 03.11.2009, Rol No 1445-09 de 29.01.2010, Rol No 1404-09 de 18.05.2010, Rol No 1394-09 de 13.07.2010,

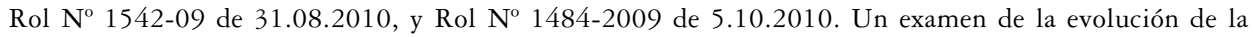
jurisprudencia constitucional en esta materia, en Piedrabuena, G., "Rol del Ministerio Público en el nuevo proceso penal”, en Revista Chilena de Derecho, vol. 30, núm. 1, Sección Estudios, 2003, pp. 11-21, y el Mismo Autor, "Jurisprudencia del Tribunal Constitucional sobre normas del Código Procesal Penal", en Revista de Derecho. Consejo de Defensa del Estado, núm. 21, jun. 2009, pp. 69-94. v.t. Aguilera, D. "La participación de la víctima en la persecución penal oficial. Análisis a partir de la jurisprudencia del Tribunal Constitucional", en Revista de Derecho, Universidad Católica del Norte, Sección: Estudios, Año 18 - N 2, 2011, pp. 53-57. La Excma. Corte Suprema de Chile dictó un acuerdo con fecha 17.01.2001 “aclarando” a los jueces de garantía los límites de sus potestades en materia de formalización.

${ }^{2}$ Para un acabado y crítico estudio sobre estas prácticas, v. Del Río F., C., Proceso penal, consenso de las partes y enjuiciamiento jurisdiccional, Librotecnia, Santiago, 2009.

${ }^{3}$ Debemos, antes de continuar, efectuar una aclaración metodológica. No es el propósito de este artículo realizar una apoyatura del principio de obligatoriedad ni del principio de discrecionalidad en el ejercicio de la acción penal, ni tomar partido sobre la conveniencia política de uno sobre otro, sino solo de demarcar y contrastar sus rasgos característicos que sean útiles para nuestro estudio. Para un análisis y confrontación, v. Hassemer, W., "La persecución penal: legalidad y oportunidad", en Jueces para la democracia, núm. 4, 1988, pp. 8-11; De Diego Díez, L., La conformidad del acusado, Tirant lo Blanch, Valencia, 1997, pp. 202 y ss.; y, 


\section{OBLIGATORIEDAD DE LA ACCIÓN PENAL}

\section{Con la expresión obligatoriedad de la acción penal aludimos al deber de la Fiscalía o} MP de iniciar, sostener y perseverar en la persecución penal de todo delito del cual tome conocimiento, sin que pueda suspenderla, interrumpirla o hacerla cesar a su discreción ${ }^{4}$.

Si seguimos a la doctrina autorizada, para la cual el ejercicio de la acción penal se materializa al formular acusación ${ }^{5}$, para que el MP pueda llegar a esa instancia, y allí

Cafferata, J., Cuestiones actuales sobre el proceso penal, $3^{\text {a }}$ ed., Editores del Puerto, Buenos Aires, 2000, pp. 21 y ss. Tampoco nos abocaremos al estudio etiológico de la dicotomía obligatoriedad-discrecionalidad, y nos concentraremos en un análisis de sus usos modernos o relativamente modernos. Sobre el fundamento teórico de los principios de legalidad y oportunidad, v. Roxin, C., Derecho Procesal Penal, Editores del Puerto, Buenos Aires, 2000, p. 89; Maier, J., Derecho Procesal Penal Argentino, T. I, vol. B, Hammurabi, Buenos Aires, 1989 , pp. 550-552 y 556. En el ámbito nacional, sobre los fundamentos del principio de legalidad, v. Maturana C. y Montero R., Derecho Procesal Penal, T. I, Legal Publishing, Santiago, 2010, p. 111, y una visión crítica en Duce, M. y Riego, C., Proceso Penal, Editorial Jurídica de Chile, Santiago, 2009, pp. 179 y ss.

${ }^{4}$ Maier, ob. cit., p. 548, indica que este principio de "legalidad", desde un punto de vista negativo, significa que ningún criterio de oportunidad -político-utilitario por conveniencia práctica, económica, temporal, etc.- autoriza, en principio, a prescindir de la persecución penal frente a la noticia de la comisión de un hecho punible. Roxin, ob. cit., p. 89, que también llama a este principio de legalidad, lo define como el deber de realizar las investigaciones cuando existe la sospecha de que se ha cometido un hecho punible y, por otra parte, de formular la acusación cuando después de las investigaciones sigue existiendo esa sospecha vehemente. En la definición propuesta en el texto se incluye lo que algunos iusprocesalistas tratan como el desdoblamiento del principio examinado en "promoción necesaria" e "irrefragabilidad", así, Clariá O., J., Derecho Procesal Penal, T. I, Rubinzal-Culzoni, Buenos Aires, pp. 234-235, alude con el primero a la promoción del proceso una vez tomado conocimiento de un hecho que encuadra con una norma penal, y con el segundo a la mantención del ejercicio de la jurisdicción hasta obtener un pronunciamiento definitivo sobre el fondo. Cafferata, ob. cit., p. 23, denomina la obligatoriedad en estos dos momentos como “inevitabilidad" e "irretractabilidad", respectivamente. Otros autores como Maier, ob. cit., p. 548; López, J. y Horvitz, M.I., Derecho Procesal Penal Chileno, T. I, Jurídica de Chile, Santiago, 2005, p. 46; y, Cerda, R. y Hermosilla, F., El Código Procesal Penal. Comentarios, Concordancias y Jurisprudencia, $2^{\mathrm{a}}$ ed., Librotecnia, Santiago, 2006, p. 189, también comprenden en el principio de legalidad a los principios de "promoción necesaria" y de "irretractabilidad".

Como se verá, hemos optado por el antagonismo obligatoriedad-discrecionalidad en el ejercicio de la acción penal, por su mayor precisión conceptual y neutralidad terminológica, siguiendo con ello a DiezPicazo, L.M, El poder de acusar, Ministerio Fiscal y Constitucionalismo, Ariel, Barcelona, 2000, p. 13.

A fin de sortear distracciones, no hablaremos tampoco de "principio de necesidad", "indefectibilidad" o nulla poena sine iudicio, que ciertos tratadistas asimilan al de obligatoriedad, pues con aquellos se suele aludir a algo distinto, a saber, que "el proceso penal es obligatorio para averiguar la infracción criminal, descubrir al autor, juzgarle y, sobre todo, imponer la pena”, Prieto-Castro, L. y Gutiérrez de C., E., Derecho Procesal Penal, $2^{\text {a }}$ ed., Tecnos, Madrid, 1982, p. 90, o en otras palabras, para referirse a la necesidad del Estado de acudir al proceso para hacer valer el ius puniendi de que es titular. En este sentido v. Gómez O., E. y Herce Q., V., Derecho Procesal Penal, $10^{\mathrm{a}}$ ed., Artes Gráficas y Ediciones, Madrid, 1987, p. 2; y, Serra D., M., Estudios de Derecho Procesal, Ariel, Barcelona, 1969, pp. 759-760. Montero A., J., Ortells R., M. y Gómez C., J., Derecho Jurisdiccional. Parte General, I. $2^{\text {a }}$ ed., Bosch, Barcelona, 1989, pp. 497-498, incluyen el aspecto comentado junto a lo que nosotros entendemos por obligatoriedad de la acción penal en el principio de necesidad procesal. Sobre el principio de indefectibilidad en el ordenamiento nacional, v. Núñez, J. C., Tratado del Proceso Penal y del Juicio Oral, T. I, Jurídica de Chile, Santiago, 2003, pp. 23-24.

${ }^{5}$ Ejercer la acción penal, strictu sensu, significa formular la acusación, según explica Prieto-Castro y Gutiérrez, ob. cit., pp. 64-65 (actuación que tiene lugar para este autor luego de practicadas las pruebas en 
ejercer la acción penal, se requiere previamente haber llevado a cabo una instrucción preliminar, sea o no formalizada, insoslayable para determinar que hay base plausible que confirme y afirme la comisión de un hecho punible del cual surja la acción penal y, unido a lo anterior, para que dicho ejercicio tenga alguna expectativa de éxito y el principio de obligatoriedad no revista un mero carácter simbólico. No hace falta gastar muchas palabras en este punto, pues no es un asunto doctrinal controvertido, aun cuando los estudios de la cátedra no suelan ser lo suficientemente explícitos sobre este aspecto en sus definiciones ${ }^{6}$.

el juicio oral), sin embargo, agrega que "como algo significan todos los actos que preceden a la formulación de las conclusiones definitivas, cabe sustentar un criterio amplio sobre la acción penal, diciendo que mediante su ejercicio se obtiene de los órganos jurisdiccionales intervinientes el descubrimiento de los actos tipificados como punibles con todas sus circunstancias, y de los autores, haciendo posible el momento de la acusación, en que propiamente se solicita la impartición de la justicia penal por la sentencia, que hace efectivo el derecho a la justicia en su bilateralidad”. Gimeno S., V., Moreno C., V., Cortés D., V., Derecho Procesal Penal, $3^{\mathrm{a}}$ ed., Colex, Madrid, 1999, p. 161, estiman que la acción penal se ejercita en el acto de iniciación del proceso penal (denuncia judicial, querella, iniciación de oficio), en tanto que la pretensión sigue un proceso escalonado que empieza en la instrucción, pasa por el escrito de acusación y culmina con las conclusiones definitivas. El Supremo Tribunal de Justicia de Portugal, en acuerdo de 14.03.1990, cit. por Rodríguez, N., La justicia penal negociada. Experiencias de derecho comparado, Ediciones Universidad de Salamanca, Salamanca, 1997, pp. 229230 , resolvió que la estructura acusatoria del proceso penal no significa de modo alguno que la acción penal se inicie con la acusación; con esta lo que comienza es una fase acusatoria más del proceso penal, ya que la acción se desencadena con la entrada en juicio de una denuncia del crimen o con su instauración, de oficio, por el MP, no circunscribiéndose a aquella fase.

En el medio nacional, Bordalí, A. "No Hay Ejercicio del Derecho Fundamental de Acción en el Proceso Penal. Sentencia del Tribunal Constitucional que Declaró Inaplicable el Artículo 230 del Código Procesal Penal", en Revista de Derecho, Universidad Austral, vol. XXI, núm. 2, diciembre 2008, pp. 248-250, y el mismo autor, "La acción penal y la víctima en el Derecho chileno", en Revista de Derecho, Pontificia Universidad Católica de Valparaíso, vol. XXXVII, $2^{\circ}$ sem. 2011, pp. 530,539-543, de estimar que la acción penal es completamente abstracta y vacía del concepto de derecho subjetivo sustancial y de interés de parte, como de un examen armónico de nuestra preceptiva constitucional y legal, limita la acción penal a la fase de acusación del proceso penal; v.t. del mismo autor "Análisis crítico de la jurisprudencia del tribunal constitucional sobre el derecho a la tutela judicial", en Revista Chilena de Derecho, vol. 38 N 2 2, 2011, p. 326. López y Horvitz, ob. cit., T. I, p. 147, también han entendido que el ejercicio de la acción penal, en rigor, se realiza en la acusación, pero precisando que entre nosotros suele utilizarse también la expresión en su sentido lato, como sinónimo de promover la persecución penal o de incoación del proceso penal, también denominado ius ut procedatur. En ese orden se ha estimado que la querella o la formalización de la investigación en nuestro ordenamiento adjetivo constituyen formas de ejercicio de la acción penal por el MP o el ofendido, cfr. Perazzo, P., "La acción en el Nuevo Proceso Penal", en Revista de Derecho Procesal, núm. 20, 2005, pp. 257 268. Nuestro TC, en control preventivo Rol N $\mathrm{N}^{\circ}$ 1001-2007 de 29.01.2008, el segundo previniente a la declaración de constitucionalidad de los inc. $1^{\circ}$ y $2^{\circ}$ del art. 132 CPP, que autoriza al abogado asistente del fiscal a comparecer a primera audiencia y formalizar la investigación y solicitar medidas cautelares dio un significado restringido a la voz "ejercer la acción penal pública" acotado a la acusación, y que por tanto no comprendía aquellos actos controlados.

${ }^{6}$ De la Oliva, A., Aragoneses, S., Hinojosa, Rafael, Muerza, J. y Tomé, J. A., Derecho Procesal Penal, $4^{a}$ ed. Centro de Estudios Areces s.a., Madrid, 1999, p. 191, explica que la acción comprende tanto el poder de provocar el inicio del proceso como "el de que se mantenga vivo a fin de ser y actuar como parte acusadora”. Del juego de los $\S 152.2$ y 170.1 StPO, Gómez C., J.L., El proceso penal alemán. Introducción y normas básicas, $1^{\mathrm{a}}$ ed., Bosch, Barcelona, 1985, p. 47, afirma que conforme al principio de legalidad, "de un lado, la Fiscalía debe practicar las investigaciones en caso de que existan sospechas de haberse cometido 
Tanto la investigación como el ejercicio estricto de la acción penal en la acusación están marcados por la legalidad procesal, regulación que limita y especifica el ámbito y extensión de las potestades del $\mathrm{MP}^{7}$. La legalidad procesal fijará entonces el cauce que la

un hecho delictivo; de otro, está obligado a formular la acusación en caso de que permanezcan, tras esas investigaciones, suficientes sospechas acerca de ese hecho". Nuestro CPP recoge la necesidad de investigar como presupuesto del ejercicio de la acción penal en su art. 77, al prescribir que: "Los fiscales ejercerán y sustentarán la acción penal pública en la forma prevista por la ley. Con ese propósito practicarán todas las diligencias que fueren conducentes al éxito de la investigación y dirigirán la actuación de la policía (...)” (la cursiva es nuestra).

${ }^{7}$ Quintero, G., y Morales, F., y Prats, M., Curso de Derecho Penal. Parte General (Acorde al Nuevo Código Penal de 1995), Cedecs, Barcelona, 1996, p. 31, explican que "el principio de legalidad, para satisfacer la reivindicación que pretendía lograr había de actuar en diversos frentes. Por ello se habla de las diversas garantías contenidas en el mismo. Estas pueden ser reconducidas a dos grandes grupos: garantías legales, que afectan el quomodo de las leyes penales (que deben ser claras, precisas, escritas, estrictas e irretroactivas) y garantías formales o procesales, referidas tanto a la determinación de los órganos en quien residía la potestad de dictar leyes como a la precisión de los órganos encargados de aplicarlas. Finalmente, el principio de legalidad habría de gobernar la ejecución de las penas". Del mismo modo, diversos autores sostienen hoy una concepción extendida del principio de legalidad, aprisionando en la misma abrazadera su aspecto material como adjetivo, así, los mismos autores citados, íbidem p. 34, consideran como garantías que derivan del principio de legalidad, las siguientes: la garantía criminal, la garantía penal, la garantía de ejecución, y la garantía jurisdiccional, significando esta última que "las sentencias condenatorias (y obviamente las absolutorias) no pueden ser dictadas más que por Tribunal competente y tras cumplir los requisitos y garantías del proceso"; Muñoz C., F., Introducción al Derecho Penal, B de F, Buenos Aires, 2001, p. 135, señala que el principio de legalidad "establece que la intervención punitiva estatal, tanto al configurar el delito como al determinar, aplicar y ejecutar sus consecuencias, debe estar regida por el 'imperio de la ley', y que por ello prefiere llamar 'principio de intervención legalizada'; Cerezo M., J., Obras Completas. Derecho Penal. Parte General, T.I., Ara Editores, Perú, 2006, p. 250, incluye dentro de las garantías que implica el principio de legalidad a la "garantía jurisdiccional”, implícita en el art. 24.2 de la Constitución española, y contenida en el art. 3.1 del Cód. Penal español, según el cual: "no podrá ejecutarse pena ni medida de seguridad sino en virtud de sentencia firme dictada por el Juez o Tribunal competente, de acuerdo con las leyes procesales”; Bustos, J. y Hormazábal, H., Lecciones de Derecho Penal, vol. I., Trotta, Madrid, 1997, p. 80, explican que "los ámbitos garantistas del principio de legalidad comprenden la garantía criminal y penal referida a la creación de normas penales (incriminación primaria); la garantía jurisdiccional y procesal referida a la aplicación de las normas y la garantía de ejecución referida a la ejecución de la pena (incriminación secundaria)"; Montero, J., Gómez C., J.L., Ortells R., M. y Monton R., A., Derecho Jurisdiccional, III. Proceso Penal, Bosch, Barcelona, 1991, p. 14; y, Bustos, J., Derecho Penal. Parte General, T. I., 2ª ed., Ediciones Jurídicas de Santiago, Santiago, 2007 , p. 379. Una aplicación extensiva del principio de legalidad a todo el sistema penal propugnó en los trabajos preparatorios del CPP chileno, Bustos, J., González, F., Riego, C., Jiménez, M.A., Vargas, J.E. y Horvitz, M.I., "El proceso penal chileno", en Corporación Nacional de Reparación y Reconciliación, Proceso Penal y Derechos Fundamentales. Colección Estudios, No 1, Santiago, 1994, p. 186. Garrido M., M., Derecho Penal. Parte General, T.I., $1^{a}$ ed., Editorial Jurídica de Chile, Santiago, 2001, p. 34, incluye en un alcance amplio del principio de legalidad a la garantía de legalidad propiamente tal, la garantía de jurisdicción, y la garantía de ejecución.

Nuestra CPR en su art. $19 \mathrm{~N}^{\circ} 3$ incs. $5^{\circ}$ y $6^{\circ}$, dispone que "Nadie podrá ser juzgado por comisiones especiales, sino por el tribunal que señalare la ley y que se hallare establecido por esta con anterioridad a la perpetración del hecho. Toda sentencia de un órgano que ejerza jurisdicción debe fundarse en un proceso previo legalmente tramitado. Corresponderá al legislador establecer siempre las garantías de un procedimiento y una investigación racionales y justos”, consagrando el principio de legalidad en el ámbito jurisdiccional, cfr. Náquira, J., Izquierdo, C., Vial, P. y Vidal, V., "Principios y penas en el derecho penal chileno", en Revista Electrónica de Ciencia Penal y Criminología, núm. 10-r2 (2008), http://criminet.ugr.es/recpc (fecha consulta: 
acción penal debe transitar a fin de obtener un pronunciamiento jurisdiccional definitivo, pero no por un específico procedimiento, ni siquiera por el procedimiento ordinario con sus habituales fases de instrucción o investigación, intermedia o preliminar, y de juicio, pues si la ley procesal ordena omitir alguna de estas fases bajo determinados supuestos, como la audiencia preliminar en el giudizio direttissimo italiano, o la de juicio oral en el procedimiento sumario portugués, en ambos casos el fiscal habrá cumplido con el ejercicio obligatorio de la acción penal. Es pertinente esta aclaración frente a la extendida doctrina por la cual se sostiene que al disponerse de una etapa del procedimiento-generalmente por la renuncia al juicio del imputado- se da espacio al principio de oportunidad ${ }^{8}$. En otras palabras, el proceso que debe impetrar el Fiscal con el ejercicio de la acción penal culminará según cuál sea la fase que el mismo ordenamiento adjetivo disponga como fase final del proceso, que no necesariamente ha de ser el juicio oral, no obstante lo cual la obligación en comento se habrá satisfecho a plenitud.

La legalidad procesal, de la cual forma parte la obligatoriedad de la acción penal, no es sino una especificación de la sumisión de todas las autoridades públicas al derecho, que nuestro ordenamiento consagra en los arts. $6^{\circ}$ y $7^{\circ}$ de la Constitución Política de la República (CPR en adelante). Ahora bien, si la ley autoriza al MP para abstenerse de la persecución penal, ya sea bajo supuestos y condiciones que la propia institución debe construir, o que la ley anticipadamente estatuye -oportunidad libre y reglada, respectivamente- ${ }^{9}$, en ambos extremos este organismo mantiene su apego a este principio de legalidad procesal, y solo ha sido dispensado de actuar según el principio de obligatoriedad de la acción penal con mayor o menor libertad ${ }^{10}$.

10-12-2011), pp. 12 y ss. El art. 83 CPR y el art. 77 CPP disponen además que el ejercicio de la acción penal debe ejercerse por los fiscales "en la forma prevista por la ley".

${ }^{8}$ Vgr. Rodríguez, N., El consenso en el proceso penal español, JMB, Barcelona, 1997, pp. 95 y 111, considera que al hacer el principio de legalidad que el MP tenga que ejercitar y sostener la acción penal "hasta la finalización del proceso", la conformidad sería, a contrario sensu, una manifestación genuina del principio de oportunidad, al poder terminarse el proceso sin la celebración del juicio oral. Califica también la conformidad española como una forma de oportunidad, entre tantos, Prada, J., "España”, en Maciá, R., Sistemas de Proceso Penal en Europa, Cedecs, Barcelona, 1998, p. 99.

${ }^{9}$ Esta división de la oportunidad ha sido asimilada rápidamente por nuestra doctrina y jurisprudencia, por lo que forma ya parte, sin ninguna duda, de nuestro acervo jurídico. Si los casos y condiciones para decidir la abstención de la acusación vienen preestablecidos en la ley, se habla de "oportunidad reglada", mientras que si se dejan esos casos y condiciones al arbitrio del MP, nos encontramos ante una "oportunidad libre", cfr. Conde-Pumpido, C., "El principio de oportunidad reglada: su posible incorporación al sistema del proceso penal español" en AAVV, La Reforma del Proceso Penal. II Congreso de Derecho Procesal de Castilla y León. Ministerio de Justicia, Madrid, 1989, pp. 290-291; y, De la Oliva, ob. cit., p. 21. Suficientemente sabido es que el modelo paradigmático de oportunidad libre es el estadounidense, mientras en el otro extremo se encuentran los modelos alemán, federal argentino y chileno, por nombrar solo algunos. Cafferata, ob. cit., pp. 33-34, entrega un concepto que creemos demasiado estrecho de oportunidad libre, acotándolo a la facultad del Fiscal de llevar a juicio solo los casos que puede ganar, en circunstancias que la esencia de la discrecionalidad radica en que, pudiendo ser el autor sujeto a una condena, el Fiscal desiste de promover su imposición. Desarrolla extensamente ambos conceptos en el ámbito nacional Duce y Riego, ob. cit., pp. 186 y ss.

${ }^{10}$ López y Horvitz, ob. cit., T.I, p. 48, reafirman que en la oportunidad libre o simplemente discrecionalidad es también el legislador quien deja a la absoluta discreción del MP el no inicio, suspensión, 
En otras palabras, lo medular de la distinción yace en que, con el principio de obligatoriedad, el MP se somete "exclusivamente" a la ley penal, tanto a la procesal que regula sus competencias y potestades en la persecución y en el proceso como a la sustantiva que debe observar al hacer sus postulaciones ante el Tribunal, mientras que con el principio de discrecionalidad el MP está sometido exclusivamente a la ley que regula sus competencias y potestades, pero estas mismas normas lo autorizan para sustraerse con mayor o menor amplitud, y mayor o menor control judicial, a la ley penal sustantiva al momento de promover la acción penal, e incorporar criterios de oportunidad en su dictamen ${ }^{11}$.

interrupción o cese de la persecución penal. Una mirada desde la doctrina administrativista corrobora este punto, al aclarar García de Enterría, E. y Fernández, T.R, Curso de Derecho Administrativo I, $12^{\text {a }}$ ed., Thomson-Civitas, Madrid, 2004, p. 461, que la estimación subjetiva propia de la potestad discrecional "no es una facultad extra-legal, que surja de un supuesto originario de la Administración, anterior o marginal al Derecho; es, por el contrario, una estimación cuya relevancia viene de haber sido llamada expresamente por la ley que ha configurado la potestad y que se le ha atribuido a la Administración justamente con ese carácter. Por eso la discrecionalidad, frente a lo que pretendía la antigua doctrina, no es un supuesto de libertad de la Administración frente a la norma; más bien, por el contrario, la discrecionalidad es un caso típico de remisión legal (...) No hay, pues, discrecionalidad al margen de la ley, sino justamente solo en virtud de la ley y en la medida en que la ley haya dispuesto”.

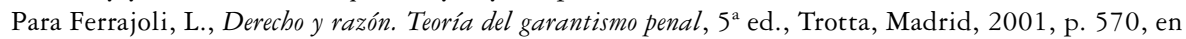
cambio, la obligatoriedad de la acción penal constituye un corolario de otros rasgos estructurales y esenciales del sistema garantista: de la legalidad o sujeción solo a la ley de toda función judicial, que excluye la posibilidad de su activación según criterios potestativos; de la indisponibilidad de las situaciones penales; del principio de igualdad penal, que excluye toda disparidad de tratamientos de los delitos ligada a opciones potestativas sobre la oportunidad del proceso. Para este autor, íbidem p. 167, el poder de disposición que compone el poder judicial no es producto de una concesión legal expresa -consecuente con su acérrima oposición a la oportunidad-, sino siempre el resultado de "carencias o imperfecciones del sistema y como tal es patológico y está en contraste con la naturaleza de la jurisdicción”. En el mismo sentido, Andrés I.P., "Por un Ministerio Público 'dentro de la legalidad', en Nueva Doctrina Penal, 1998/B, Editores del Puerto, Buenos Aires, 1998, pp. 455 y ss. y el mismo en “El Ministerio Fiscal entre 'viejo' y 'nuevo' proceso”, en Revista de Ciencias Penales, No especial Ministerio Público, 1990-1993, p. 76, n. 106; Hassemer, ob. cit., p. 10, sostiene que mientras un derecho penal albergue supuestos de oportunidad, el respeto al Estado de Derecho por parte del procedimiento dependerá de si los casos están determinados con absoluta precisión; las reglas de oportunidad vagamente formuladas destruirían por completo el principio de legalidad, y la persecución penal oportunista se extendería de forma epidémica sin forma de controlar ni limitar las decisiones de las autoridades instructoras de no perseguir un delito; De Diego D., ob. cit., p. 215, añade sobre la oportunidad libre lo siguiente: "un sistema tan abierto, que rompe con toda idea de plena sumisión a la ley y al Derecho dado, resultada extraño a nuestra cultura jurídica [europeo-continental] y a nuestra concepción de un Estado de Derecho y pugna, además, con los sentimientos de justicia de nuestra sociedad, por lo que difícilmente es trasladable a nuestro ordenamiento". En el ámbito nacional, exigiendo que los criterios preventivos en los que se base el principio de oportunidad estén determinados de modo general y objetivo en la ley, a fin de respetar el principio de legalidad del derecho penal, v. López y Horvitz, ob. cit., T.I, p. 452.

${ }^{11}$ Como sentencia Zagrebelsky, V., "Independencia del ministerio público y obligatoriedad de la acción penal”, en Revista de Ciencias Penales, No especial Ministerio Público, 1990-1993, p. 115, "el núcleo esencial del principio de obligatoriedad de la acción penal reside en el exclusivo sometimiento a la ley de quien está llamado a ejercerla y se resuelve en un aspecto del principio de legalidad, asumiendo esencial relieve en el plano de la subdivisión de competencias entre magistratura y otros poderes del Estado”. 
Este apartamiento de la ley penal sustantiva no responde entonces a la disposición de una relación jurídico material nacida del hecho entre el acusador y acusado, en virtud de la cual aquel posea un derecho subjetivo a pedir la condena de este ${ }^{12}$, es decir, a ejercer una pretensión punitiva, sino una mera autorización legal en aras de otros intereses o valores estimados en el caso como superiores a la estricta observancia de la legalidad penal.

Se yerra por ende al situar como antagonista de la discrecionalidad -u oportunidad-al principio de legalidad procesal si es la propia ley la que concede potestades discrecionales al Fiscal para sustraer un hecho o sujeto de la persecución, antagonismo que en realidad se presenta con el de obligatoriedad de la acción penal ${ }^{13}$. De ese modo, este par dialéctico - discrecionalidad y obligatoriedad- tienen un mismo campo de juego, esto es, las facultades y límites de los poderes públicos, ya que vienen siempre referidos al Fiscal y/o al Juez, así como a las funciones que uno y otro desempeñan en el proceso penal ${ }^{14}$.

Por lo argumentado es que la disección entre oportunidad "reglada" y "libre" radicará simplemente en la menor o mayor licencia que el legislador dispensa al MP para forjar una política de actuación propia, pero ambas modalidades de oportunidad se cimentan necesariamente en el principio de legalidad. En la oportunidad reglada tal discrecionalidad se restringe generalmente a la delincuencia bagatelaria y bajo ciertas condiciones en las cuales el legislador estima ausente un interés público en la persecución, o privilegia otros valores. Pero cumplidos dichos supuestos y condiciones -regularmente bajo supervisión judicial- siempre debe residir en el Fiscal la elección discrecional del abandono o promoción de la persecución penal -por ende, sin revisión judicial de mérito-, pues de no conservar estas opciones -y aquí queremos romper con un lugar común en la doctrina nacional- no se puede ya hablar de oportunidad o discrecionalidad política,

12 Cobo del Rosal, M. y Vives Antón, T., Derecho Penal. Parte General, 4ª ed., Tirant lo Blanch, Valencia, 1996, pp. 56-58, explican esto de la siguiente forma: "el Estado no comparece en el proceso penal a realizar 'su' derecho, sino a pedir la realización del derecho objetivo, que es tanto el derecho de la víctima cuanto el del delincuente". Precisan que el MP no comparece en el proceso a defender sus intereses "porque constitutivamente carece de un interés propio que no sea el del cumplimiento de la ley”. Continúan apuntando que "la inadecuación de la noción de derecho subjetivo es aún más patente si se acepta que la potestad punitiva radica en los Tribunales. Mal puede hablarse de un derecho subjetivo ejercitado por el Ministerio Fiscal, que es una 'parte imparcial' en el proceso y, por ello, una parte desinteresada; pero menos aún cabe atribuir a los Tribunales derecho subjetivo alguno. El poder de juzgar es sencillamente la potestad de aplicar derecho objetivo, y así ha sido concebido, casi invariablemente, por la doctrina española”.

${ }^{13}$ Conde-Pumpido, ob. cit., pp. 290-291, complementa que la conexión entre el principio de oportunidad y el ejercicio de la acción penal ha hecho actualmente más que contraponer el principio de oportunidad al de legalidad, se diga que realmente a lo que se contrapone el uso de la oportunidad por el MP es al principio de obligatoriedad de la acusación.

${ }^{14}$ Cfr. Aguilera, E., El "principio de consenso". La conformidad en el Proceso Penal Español, $1^{\text {a }}$ ed., Cedecs, Barcelona, 1998, p. 135; Berzosa, M ${ }^{a}$ V, "Los principios de legalidad y oportunidad en el proceso penal”, en Picó I Junoy, J. (Dir.), Problemas actuales de la Justicia Penal, Bosch, Barcelona, 2001, p. 16; Armenta D., T., Criminalidad de bagatela y principio de oportunidad: Alemania y España, PPU, Barcelona, 1991, p. 185; Dworkin, R., Los derechos en serio, $4^{\mathrm{a}}$ reimp., Ariel, Barcelona, 1999, pp. 83-84, suscribe que la expresión "discrecional" solo cabe en un único tipo de contexto, "cuando alguien está en general encargado de tomar decisiones sujetas a las normas establecidas por una autoridad determinada". 
sino simplemente de una discrecionalidad técnica -que luego comentaremos-, la que no quebranta el principio de obligatoriedad ${ }^{15}$. La doctrina administrativista nos da luces al respecto, al señalar que solo en los casos en que las decisiones no se completan en vía legislativa, y el órgano puede contribuir a determinarlas usando opciones políticas propias, definidas con independencia, las potestades que ejercita pueden denominarse discrecionales ${ }^{16}$.

${ }^{15}$ Lleva la razón entonces Ruiz V., E., "El principio de oportunidad reglada", en AAVV, La Reforma del Proceso Penal. II Congreso de Derecho Procesal de Castilla y León, Ministerio de Justicia, Madrid, 1989, pp. 396 y ss., cuando asevera que la oportunidad reglada no es oportunidad, sino legalidad, tratándose de un problema puramente terminológico. El mismo, en Estudios de Derecho procesal penal, Comares, Granada, 1995, pp. 76-77, insiste en que si la oportunidad "viene establecida por la ley y está sujeta a determinadas reglas o pautas de comportamiento (...) entonces la oportunidad reglada se hace legalidad y su aplicación es correcta y ortodoxa". Ejemplifica incluso señalando que si la ley penal condiciona la persecución del delito a que este "perturbe gravemente el servicio público" se está confiriendo una importante facultad de apreciación para juzgar la presencia del delito o su gravedad que sigue respetando el principio de legalidad, porque el delito se condiciona por la propia ley a determinados y puntuales supuestos. Concordantemente, Delgado, J., "El principio de oportunidad en el proceso penal", en AAVV, La Reforma del Proceso Penal. II Congreso de Derecho Procesal de Castilla y León, Ministerio de Justicia, Madrid, 1989, p. 314, indica que al venir dados por el legislador todos los criterios para seleccionar las conductas en la aplicación de la norma penal, normalmente a través de conceptos jurídicos indeterminados, no nos encontraríamos ante un principio de oportunidad, sino ante un principio de selección reglada. En esa línea, por no ser en realidad la oportunidad reglada, así entendida, verdadera oportunidad, es que autores como Cafferata, ob. cit., p. 34, requiere en aquella el control del órgano jurisdiccional sobre si el caso es de los que la ley autoriza abstractamente a tratar con criterios de oportunidad, y sobre si amerita concretamente dicho tratamiento; y, Conde-Pumpido, ob. cit., pp. 304-305, sostiene que el principio de oportunidad reglada asegura de por sí un tratamiento general idéntico para casos análogos -atributo que justamente se echa de menos en la verdadera oportunidad-.

Diversos autores avalan la necesidad de un espacio desregulado para que opere la oportunidad, cfr. Aguilera, ob. cit., p. 144, quien anota que la ley podrá determinar el ámbito en que puede operar la oportunidad, los presupuestos, requisitos y condiciones necesarios para que aquella alcance virtualidad; $\mathrm{y} / \mathrm{o}$ los medios de control para asegurar que el MP no incurra en arbitrariedad, pero no la oportunidad en sí misma, esto es, el margen de decisión que la discrecionalidad comporta, so pena de dejar aquel concepto (la oportunidad) vacío de contenido. La oportunidad no puede estar sometido a más reglas que las que en cada momento sugiera el criterio del Ministerio Fiscal; Berzosa, ob. cit., p. 17, reafirma que el concepto de "oportunidad reglada" encierra "en sus propios términos cierta contradicción, ya que el ejercicio de estas facultades o, expresado de otro modo, la apreciación discrecional es algo que no puede ser reglado"; Armenta, ob. cit., pp. 210-211, explica que con la denominación de oportunidad reglada "se pretende obviar las críticas formuladas contra el principio de oportunidad, derivadas de la vigencia del principio de legalidad, como principio informador de nuestro ordenamiento [español]. Añadiendo el adjetivo 'reglada' -se argumenta- es la propia ley quien fija las condiciones de aplicación del principio de oportunidad y, por ende, no constituye una excepción sino una variedad de la propia legalidad. A mi juicio, la utilización del calificativo 'reglada' no tiene -como parece se ha pretendido- un efecto sanatorio en el sentido de que el simple empleo del mismo tendría como consecuencia subsanar las posibles quiebras al principio de legalidad que pudieran producirse"; Zagrebelsky, ob. cit., p. 116, a quien la dificultad para individualizar un ámbito de discrecionalidad guiada por indicación precisa de la ley le llevó a concluir que la posibilidad de regulación de la acción penal se reduce a la alternativa: obligatoriedad o discrecionalidad política; y, De la Oliva, ob. cit., p. 22.

${ }^{16}$ Muñoz, S., Tratado de Derecho Administrativo y Derecho Público General, T.I., $1^{\text {a }}$ ed., Thomson-Civitas, Madrid, 2004, p. 519. De lo contrario, si la ley determina agotadoramente todas y cada una de las condiciones de ejercicio de la potestad, de modo que construya un supuesto legal completo y una potestad aplicable al mismo también definida en todos sus términos y consecuencias, nos hallamos frente a una potestad reglada que no deja resquicio a juicio subjetivo ninguno, García de E.y Fernández, ob. cit., pp. 460-461. En el 
De acuerdo con lo dicho entonces, el poder discrecional no es susceptible de graduaciones; existe o no. O el MP es libre para actuar en un determinado sentido o no lo es. Sin embargo, en los actos del MP puede haber mayor o menor discrecionalidad según la regla de derecho deje más o menos elementos a la libre decisión del Fiscal ${ }^{17}$. Por ello puede ser conveniente, en cuanto técnicamente más riguroso, examinar las instituciones procesales específicas de un determinado sistema legal según los elementos reglados y discrecionales que se aprecien en su estructura normativa y que incidan en el ejercicio y promoción de la acción penal por el MP. Los elementos reglados del precepto impondrán al MP tener en cuenta ciertos requisitos que ella establece, de tal suerte que en presencia de predeterminadas circunstancias deberá actuar en el sentido prescrito por la norma, mientras que los segundos facultan al MP para obrar libremente sin que su conducta esté anticipadamente fijada por la regla de derecho. Así, la relación entre estos elementos es de exclusión, pues en la medida que un elemento no sea reglado será residualmente discrecional, y por tanto no susceptible de control judicial ${ }^{18}$.

Demos un paso más. La investigación y la acusación además están indisolublemente enlazadas a la legalidad en su vertiente sustantiva, no porque la acción penal comprenda la calificación jurídica concreta (dentro de la causa petendi) y la sanción o petitum postulada por el MP como pretensión procesal en su acusación, sino porque la delimitación del hecho que constituirá el objeto del juicio -y que por exigencias del principio acusatorio le corresponde fijar al MP u otro organismo ajeno al Tribunal decisor- solo puede realizarse teniendo como referencia lo que la ley sustantiva establece como delito -y circunstancias modificativas de responsabilidad penal-, atendido el carácter fragmentario del derecho penal, debiendo en consecuencia requerirse la sanción anunciada previamente por el

panorama doctrinal administrativista y local el par potestad discrecional-potestad reglada tiene añosa recepción, para un rápido compendio, v. Alarcón J., P., Discrecionalidad Administrativa. Un estudio de la jurisprudencia chilena, LexisNexis, Santiago, 2000, pp. 13 y ss. Ortells R., M., "Cuatro aproximaciones al nuevo proceso penal chileno desde la perspectiva del proceso penal en países de la Unión Europea”, en AAVV, El Nuevo Proceso Penal Chileno, Facultad de Ciencias Jurídicas y Sociales. Dpto. de Derecho Procesal. Universidad de Concepción, 2000, pp. 313-314, se vale de este binomio potestad reglada-discrecional para referirse a la configuración jurídica de la potestad de acusar del MP.

${ }^{17}$ Se ha seguido en esto a Pierry A., P., "El control de la discrecionalidad administrativa", en Revista Chilena de Derecho, vol. 11, 1984, p. 480, en sus apreciaciones sobre el acto administrativo.

${ }^{18}$ En relación con las potestades de la Administración, Muñoz M., ob. cit., p. 525, habla de los "elementos reglados que siempre integran cualquier potestad discrecional”, los cuales pueden controlarse judicialmente; García de Enterría y Fernández, ob. cit., pp. 460 y ss., precisan que no hay potestades discrecionales absolutas y solo existen elementos de dicha atribución que pueden tener rasgos de ese carácter. Por eso, se afirma que en las potestades íntegramente regladas los elementos que las configuran (su titular, la forma en que se ejercen, su finalidad, la forma que adoptan los actos que se dictan en su ejercicio, la oportunidad de su ejercicio, los hechos y fundamentos en que se fundan, etc.) están detalladamente definidos por la norma que las confiere. En la potestad discrecional, en cambio, hay uno o más de dichos elementos abiertos, entregados al órgano respectivo para ser completados por su apreciación subjetiva. Ello implica que el órgano debe optar entre elementos igualmente justos o equivalentes; Pierry, ob. cit., p. 480, a su turno, apostilla que en cada acto administrativo existe un aspecto reglado y un aspecto discrecional, siendo excepcionales los casos de actos exclusivamente reglados, e imposibles de concebir los actos puramente discrecionales. Añade que el control de la legalidad recae sobre el aspecto reglado del acto o actuación de la Administración, sin que el aspecto discrecional sea susceptible de control alguno. 
legislador para ese hecho delictivo y no otro. Digámoslo de otra forma, la pretensión punitiva que obligatoriamente deberá perseguir el MP es aquella que corresponde al delito en el que se encuadra el hecho de que ha tomado noticia, investigado y acreditado, y no otra. Ergo, si hay indicios suficientes de la comisión del delito de violación, por ejemplo, el principio de obligatoriedad de la acción penal impone al MP acusar por ese delito y no otro, y no acusar nada más; e igualmente, si se cuenta con respaldo para acreditar una circunstancia agravatoria de ese delito de violación, el principio de obligatoriedad de la acción penal demanda al fiscal no únicamente acusar por el delito de violación, sino por el delito de violación y sus circunstancias agravatorias. Como afirma Jiménez de Asúa: "de la ley surge la pretensión punitiva del Estado a reprimir los actos catalogados en su texto como delitos, con la pena conminada, y por eso la ley es, a la vez, fuente y medida del derecho de penar" ${ }^{19}$, o en las palabras de Maier, el principio de legalidad significa que "ante la afirmación hipotética de un conflicto social generado por la inobservancia a una norma penal, el acontecimiento real sucedido y la ley penal sean los únicos parámetros posibles de solución para el caso, razón la cual es preciso inquirir la verdad de aquello que ha sucedido, limitadamente a los elementos importantes para la solución del caso, según la ley penal, y decidir el problema únicamente por aplicación de la ley penal, de la pena estatal, en su caso" ${ }^{20}$. Obrando así, el MP representa "el puente entre el programa abstracto del legislador penal y su realización concreta, esto es, su funcionamiento real; el nexo institucional entre la criminalización primaria y secundaria" ${ }^{21}$.

De no aceptarse esta concatenación entre la legalidad procesal y la sustantiva, el MP daría fácilmente al traste con la indisponibilidad de la acción penal -u objeto del proceso penal, o conflicto penal-, mediante su ejercicio meramente formal o ritual, en el que, sin suspender, interrumpir o cesar completamente su impulso, introduzca como objeto del juicio hechos recortados que obsten al Tribunal para aplicar correctamente la ley penal en virtud de las limitaciones que conlleva el principio acusatorio, o persiguiendo la imposición de sanciones inferiores a las prescritas por la ley en aquellos procedimientos en que la pretensión punitiva del Fiscal sea vinculante para el Juez. En este encuadre del hecho al derecho, salvo que la ley autorice al MP actuar a su arbitrio o discreción, debe atenerse exclusivamente a la correcta aplicación de la legalidad sustantiva ${ }^{22}$, obligación que implica asimismo, que la sanción que el Fiscal postule en su acusación debe ajustarse únicamente a la ley penal sustantiva, salvo, otra vez, que la ley autorice a sopesar criterios de oportunidad en ella ${ }^{23}$.

\footnotetext{
${ }^{19}$ Jiménez de Asúa, L., Principios de Derecho Penal. La Ley y el Delito, Abeledo-Perrot, Buenos Aires, p. 92.

${ }^{20}$ Maier, J., Derecho Procesal Penal. II. Parte General. Sujetos procesales, 1ª ed., Editores del Puerto, Buenos Aires, 2003, p. 322.

${ }^{21}$ Mera F., J., "Comentario de Jorge Mera”, en AAVV, El Ministerio Público para una nueva justicia criminal, Fundación Paz Ciudadana, Escuela de Derecho Universidad Diego Portales, Corporación de Promoción Universitaria, Santiago, 1994, p. 167.

22 Obligación que nuestro ordenamiento expresamente impone al acusador público (art. 3 LOCMP).

${ }^{23}$ En tal sentido para Asencio M., J.M., Principio Acusatorio y Derecho de Defensa en el Proceso Penal, $1^{a}$ ed., Trivium, Madrid, 1991, p. 55, el binomio legalidad-necesidad implica también la imposibilidad "de reducción o mutación del hecho o la variación de la calificación jurídica o de la pena fuera de los márgenes
} 
Disipemos sí que, pese al vínculo expuesto entre el principio de obligatoriedad de la acción penal y el de legalidad sustantiva, no hay entre estos identidad. Este último principio suele erróneamente ser entendido retributivamente como un "deber de castigar”, y además, de castigar solo con la pena establecida en la ley y no otra, tampoco otra menor, y por ello, como naturalmente opuesto al principio de discrecionalidad u oportunidad $^{24}$. Pero el principio de legalidad, consagrado en la mayoría de las Constituciones occidentales con fórmulas negativas, que prohíbe castigar conductas e imponer penas no previstas en la ley con anterioridad a la perpetración del ilícito ${ }^{25}$, configura un cerco normativo al ius puniendi estatal, y en caso alguno se desprende de ella una formulación positiva tal como "todos los que cometan delito deben ser castigados con la pena que señale la ley" ${ }^{26}$. De ahí que la garantía constitucional de legalidad sustantiva no sea ni

autorizados por la ley"; y, por el contrario, pasa a ser parte del principio de oportunidad la posibilidad de interesar pena inferior a la legalmente prevista, cfr. Aguilera, ob. cit., p. 136.

${ }^{24}$ Cfr. Hassemer, ob. cit., p. 8, asevera que el derecho penal material determina no solo los límites de la punibilidad, sino que tiene además la misión de reafirmar y asegurar las normas fundamentales de una sociedad. El aseguramiento de las normas presupone que en el proceso penal se van a aplicar tal y como el derecho material las dispone, es decir, según la legalidad jurídico-material; Bettiol, G., Instituciones de derecho penal y procesal, Bosch, Barcelona, 1977, pp. 198 y 200, postula que la obligación de aplicar la pena deriva de cada norma de carácter sustancial; Soto P., M., "Ministerio Público y Política Criminal", en AAVV, El Ministerio Público para una nueva justicia criminal, Fundación Paz Ciudadana, Escuela de Derecho Universidad Diego Portales, Corporación de Promoción Universitaria, Santiago, 1994, p. 141, indica que, "si bien debe admitirse que la instauración del principio de legalidad sustancial y procesal constituyó una inevitable ventaja y una garantía frente a la arbitrariedad que gobernaba la persecución penal en el anciene regime, del mismo modo debe concederse también que dicha instauración representó una clara limitación, de significación preventiva, a la posibilidad cierta de que el arbitrio judicial pudiera volverse a favor de la no persecución"; y, Rico, J.M., Justicia penal y transición democrática en América Latina, Siglo Veintiuno editores, México, 1997, atribuye al principio de legalidad -que entiende como la imposibilidad de suspender el ejercicio de la acción penal una vez interpuesta- el carácter de "base de un estado de derecho". En España, diversos autores defienden que el art. 100 LECrim, al disponer que "de todo delito o falta nace acción penal para el castigo del culpable”, se está consagrando la obligatoriedad de la acción penal, en vez de muchos, v. Prada, ob. cit., p. 99 (n. 23).

${ }^{25}$ El principio de legalidad, en la formulación latina acuñada por Feuerbach, nullum crimen, nulla poena sine lege praevia, se constituye en una de las conquistas centrales de la Revolución Francesa y queda plasmado en el art. $8^{\circ}$ de la Declaración de los Derechos del Hombre de 26 de agosto de 1789. Sobre la evolución y origen histórico del principio de legalidad, v. Muñoz C., ob. cit., pp. 137 y ss.; y, Welzel, H., Derecho Penal Alemán, $4^{a}$ ed., Ed. Jurídica de Chile, Santiago, 1997, pp. 22 y ss.

En el ordenamiento nacional, el principio de legalidad se recoge en el art. $19 \mathrm{~N}^{\circ} 3$ incs. $8^{\circ}$ y $9^{\circ} \mathrm{CPR}$, y se reitera a nivel legal en los arts. $1^{\circ}$ y $18 \mathrm{CP}$.

${ }^{26}$ Así lo propugna Vives A., T.S., La reforma del proceso penal. Comentarios a la ley de medidas urgentes de reforma procesal II, Tirant lo Blanch, 1992, pp. 285-295, al analizar la compatibilidad de la oportunidad con el principio de legalidad contemplado en el art. 25.1 de la Constitución española ("nadie puede ser condenado o sancionado por acciones u omisiones que en el momento de producirse no constituyan delito, falta o infracción administrativa, según la legislación vigente en aquel momento”). Puntualiza este jurista que, con razón ha hablado la jurisprudencia constitucional española de la legalidad como un derecho susceptible de amparo: aquel principio negativo que, desde la perspectiva del imputado o condenado, es un derecho fundamental, no se quebranta porque, allí donde la pena adecuada a la culpabilidad no cumple sus fines, puede ser sustituida por otras más leves, o por medidas o, simplemente puede renunciarse a ella. De manera similar, ahora respecto de la normativa constitucional argentina (art. 18 Constitución de la Nación 
equivalente al principio de obligatoriedad de la acción penal, ni obstaculice incorporar legislativamente el principio de discrecionalidad u oportunidad. En otras palabras, el

Argentina), se ubica Cafferata, ob. cit., p. 24. Nuestro máximo Tribunal también manifestó criterio análogo en SCS Rol No 139-2002 de 27.03.2002, al decidir que: "es bastante dudoso que el MP con la intención de sancionar más severamente a un imputado de un delito pueda fundar la nulidad en el principio de reserva constitucional que históricamente se ha establecido para contener el poder del Estado en el ejercicio del ius puniendi y, por lo tanto, resultan tales principios baluartes de defensa de personas que, incriminadas, puedan resultar condenadas por hechos no sancionados por la ley, no tipificados adecuadamente o no establecidos como delictivos a la época de su comisión y por ello no resulta admisible invocar tales principios para imponer penas mayores a las aplicadas al imputado".

A mayor abundamiento, Bustos y Hormazábal, ob. cit., p. 88, explica limpiamente que el fundamento último del principio de legalidad es la exclusión de la arbitrariedad dentro de la relación individuo-Estado, "luego, desde esa perspectiva, el principio de legalidad no puede ser fuente de una obligación de perseguir penalmente (...). Para sostener la obligación de la persecución penal se suele confundir el principio de legalidad con el de oficialidad. El principio de oficialidad es el que obliga a la acción penal, no el de legalidad. Frente al principio de oficialidad se sitúa el principio de oportunidad. Este último deja dentro de la discrecionalidad la persecución penal"; Maier, Derecho Procesal Argentino, ob. cit., pp. 551-552, da cuenta de la paralela relación existente entre el principio legalidad sustantivo y el principio de oportunidad: "cabe advertir que estos principios [de igualdad ante la ley y la determinación legislativa de los hechos punibles] funcionan básicamente como garantía frente al poder penal del Estado, esto es, como seguridades para el habitante de no ser afectado en sus libertades por ese poder, y aquello que se pretende con la aplicación del principio inverso, el de oportunidad, no es precisamente someter a un habitante al poder del Estado, sino, por el contrario, liberarlo de él y de ese riesgo, al evitar su persecución”; asimismo, López y Horvitz, ob. cit., T. II, p. 485 (n. 58) avalan que "el principio de legalidad jamás ha sido entendido a favor del Estado o de la sociedad, sino del ciudadano, a quien el propio Estado le garantiza que no intervendrá punitivamente sobre él en tanto el hecho que se le impute no se encuentre previsto y descrito en una ley dictada con anterioridad a la comisión del hecho"; y, con agudeza, Couso S., J., "Oportunidad versus legalidad: entre economía políticocriminal, despenalización, prevención y principios garantistas”, en Cuadernos de análisis jurídico, núm. 39, 1998, pp. 185-186, plantea la relación inversa que existe entre el principio de legalidad sustantiva y el de obligatoriedad de la acción penal -que prefiere denominar legalidad procesal- de la siguiente forma: "a primera vista la legalidad procesal es la cara positiva de la legalidad penal: si esta impide castigar (y perseguir penalmente) por un hecho no descrito legalmente como delito, la primera exige perseguir penalmente (y en su caso castigar) cuando se está ante un supuesto hecho que calza en la descripción legal (salvo que ocurran eximentes). Pero, salvo ciertos extremos, en principio parece que la legalidad procesal-penal y la legalidad penal corren por vías independientes entre sí, de modo que, en principio, la relajación de la legalidad procesal-penal (mediante la introducción del principio de oportunidad) no incide necesariamente en una relación de la legalidad penal: es decir, parece posible que, aun cuando no se persigan todos los delitos, solo se persigan conductas descritas por la ley, en forma previa y precisa, como delitos. La legalidad procesal-penal, en realidad, tiene más relación con el principio de igualdad que con el de legalidad penal”.

Es así como la CIDH no ha deducido del principio de legalidad consagrado en el art. 9 de la CADH ("nadie puede ser condenado por acciones u omisiones que en el momento de cometerse no fueran delictivos según el derecho aplicable”), una obligación de sancionar a todo hechor de todo delito, y solo ha declarado como obligación de garantía el deber de los Estados suscriptores de investigar y sancionar las violaciones de derechos humanos, cfr. Zalaquett, J. y Nash, C., "Proceso Penal y Derechos Humanos", en Revista de derecho procesal, Dept. de Derecho Procesal, Facultad de Derecho, Universidad de Chile, núm. 20, 2005, pp. 71 y ss, y 81 y ss., y Barros, L., Frühling, H., García, G., Quintana, A. y Sánchez, D., "El proceso penal chileno y su protección de los derechos del imputado", en Proceso Penal y Derechos Fundamentales. Colección Estudios, No 1, Corporación Nacional de Reparación y Reconciliación, Santiago, 1994, p. 109 y ss. Sobre el punto se puede revisar la sentencia recaída en el Caso Velásquez Rodríguez de 29.07.1988, donde a partir del art. $1^{\circ}$ de la CADH ("Los Estados Partes en esta Convención se comprometen a respetar los derechos y libertades reconocidos en ella y a garantizar su libre y pleno ejercicio a toda persona que esté sujeta a 
principio de legalidad hoy es, ante todo, un postulado de "garantía"27, que "condiciona" la legitimidad del uso del ius puniendi por parte del Estado al establecimiento previo por ley del delito y la pena, pero ello no "impone" -al menos no en virtud de este principio-su ejercicio.

Por último, en el proceso regido por el principio acusatorio, una vez impuesto el órgano jurisdiccional de la prueba de cargo en el juicio, nace para él el deber de condenar, si fuera el caso, y no omitir discrecionalmente la sanción por motivos de oportunidad o conveniencia, salvo autorización legal ${ }^{28}$. Tal cometido no debe ser visto como una expresión a nivel jurisdiccional del principio de obligatoriedad de la acción penal, pues en un sistema gobernado por el principio acusatorio la judicatura no ejerce la acción penal sino solo declara la responsabilidad penal según el derecho objetivo vigente. Como bien explica Bordalî́29, "la acción penal es una simple prolongación del principio de legalidad. Con la acción se activa el proceso penal. Tanto el Ministerio Público como el tribunal cumplen con sus deberes de realizar las prescripciones dispuestas por la

su jurisdicción...”), la CIDH deriva la obligación de los Estados de "prevenir, investigar y sancionar toda violación de los derechos reconocidos por la Convención” (cons. 166).

Oo. Ruiz V., E., Estudios de Derecho procesal penal, Comares, Granada, 1995, p. 64, se inclina por incluir los distintos frentes comentados del principio de legalidad en el principio constitucional contenido en el art. 25.1 de la Constitución española; De la Oliva, ob. cit., pp. 22, 24-25, inserta el principio de obligatoriedad dentro del ejercicio de las funciones del MF con sujeción al principio de legalidad que mandata el art. 124.2 de la Constitución española, y además puntualiza que aunque el art. 25.2 del mismo texto no formula expresamente el ius puniendi como deber del Estado de castigar, sí presupone ese deber del Estado respecto de las conductas que sean tipificadas como delitos; Montero, et al., Derecho Jurisdiccional. Parte General, ob. cit., p. 497-498, reconociendo que el art. 124 precitado no dice que todos los delitos deben originar un proceso, acude con dicho objeto a los preceptos más generales que sujetan los poderes públicos al ordenamiento jurídico, principio de legalidad y seguridad jurídica (art. 9) y a la interpretación de la Constitución conforme a los tratados internacionales (art. 10); de manera similar, conjugando el principio de legalidad sustantivo con los arts. 9 y 124, Aguilera, ob. cit., p. 143; y, Del Río F., C., "El principio del consenso de las partes en el proceso penal y enjuiciamiento jurisdiccional: aclaraciones conceptuales necesarias", Revista Chilena de Derecho, vol. 35, núm. 1, 2008, p. 174, arguye que el principio de legalidad penal, amén de su contenido de garantía, también implica un mandato ineludible en orden a que se debe aplicar la norma sancionada en la ley, y no otra, de manera que la ley penal no opera solamente como un techo o tope máximo, dejando hacia abajo amplios márgenes de discrecionalidad al acusador y para el juzgador, como áreas para crear normas penales atenuadas aplicadas a casos particulares.

${ }^{27}$ Quintero, et al., ob. cit., p. 33. Es un lugar común en la doctrina ver el principio de legalidad como un principio "limitador" al poder punitivo del Estado, entre tantos, v. Bovino, A., Problemas del derecho procesal penal contemporáneo, Editores del Puerto, Buenos Aires, 1998, p. 72; Muñoz C., ob. cit., pp. 135 y ss.; Garrido, ob. cit., T. I, p. 30, concluye que el principio de legalidad o de reserva en esencia consiste en una "autolimitación del propio Estado"; para Bullemore, V. y Mackinnon, J., Curso de Derecho Penal. Parte General, T.I., $1^{\text {a }}$ ed., LexisNexis, Santiago, 2005, p. 27, es uno de los medios limitadores del derecho de castigar del Estado. Una visión del principio de legalidad desde la óptica de los derechos humanos en Mera, J., Derechos Humanos en el Derecho Penal Chileno, Conosur, Santiago, 1998, pp. 62 y ss.

${ }^{28}$ En el procedimiento alemán, habiendo la Fiscalía ya presentado cargos, el juez, con el consentimiento de aquella y del acusado puede terminar el proceso definitiva o provisionalmente -sujeto el imputado en este caso a condiciones-, dándose los presupuestos previstos en la ley ( $\$ 153$ y 153 a StPO). Similar mecanismo contempla el art. 280.2 del CPP portugués (archivo en caso de dispensa de pena).

${ }^{29}$ Bordalí, La acción penal, ob. cit., p. 530. 
norma penal positiva. Ambos, el Ministerio Público que ejerce la acción penal y juez que conoce y resuelve la acusación, están vinculados al principio de legalidad”. Y como reafirma Bovino, "el principio de legalidad solo obliga al ministerio público -pues él es el titular de la acción penal pública-, y no a los demás órganos del Estado. Si bien se puede controlar al ministerio público, su incumplimiento no autoriza a que se atribuyan sus obligaciones a otro órgano estatal (...) Ahora bien, 'controlar' no significa 'actuar en lugar de', es decir, controlar el ejercicio de la acción del ministerio público no significa actuar en lugar del ministerio público" 30 . Más bien creemos cabe hablar de complementariedad, de nada serviría compeler al Fiscal a promover una persecución frente a jueces que no estarán a su turno constreñidos a sancionar ${ }^{31}$. Y este deber de castigar, si procediere por parte del órgano jurisdiccional, deriva del carácter público del ius puniendi que materializa con su sentencia, derecho público que está subordinado siempre al ejercicio de su función -a diferencia de los derechos de los particulares-, y como tal debe ejercitarse en forma necesaria. Es así sustentable que "todo derecho público implica al propio tiempo un deber de ejercicio y que, en términos de derecho público, facultad de castigar y deber de castigar son términos correlativos" 32 .

\section{DisCRECIONALIDAD EN EL EJERCICIO DE LA ACCIÓN PENAL}

El concepto antagonista a la "obligatoriedad" es el de "discrecionalidad" en el ejercicio de la acción penal, y con ello apuntamos a la autorización legal dada al MP para

${ }^{30}$ Bovino, ob. cit., pp. 27-28.

31 En los sistemas del common law que encomiendan a un jurado compuesto por miembros de la comunidad, decidir si el acusado tiene o no responsabilidad penal en los cargos formulados por la Fiscalía, sin demandárseles que justifiquen uno u otro dictamen, es factible que una decisión de no culpabilidad se base en aspectos tan diversos como la simpatía que les genere el defendido, la impopularidad de la ley penal en cuestión, etc., y no en la insuficiencia de evidencia. El jurado puede entonces obstaculizar en el caso concreto la aplicación de la ley penal vigente, lo que es conocido como jury nullification, mediante un veredicto que además no podrá ser objeto de recursos u otros medios de revisión. Por ello, con la fórmula jury nullification se alude al poder del jurado para absolver incluso cuando los hechos por ellos establecidos, si fueran literalmente aplicados a la ley como fue declarada por el juez, habría resultado en una condena, cfr.

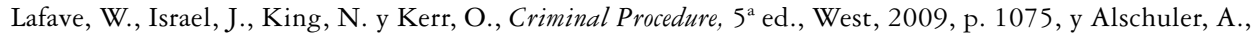
"Jury: Legal Aspects", en AAVV, Encyclopedia of Crime E Justice, vol. 2, 2a ed., Macmillan Reference USA, New York, 2002, p. 880-881. Frente a este Tribunal que no tiene una obligación exigible o revisable de condenar, no parece tan inapropiado situar en el otro extremo del sistema de justicia a un Fiscal también con amplia discrecionalidad, por sobre la aplicación estricta de los estatutos criminales en un caso específico.

32 Serra, ob. cit., pp. 758-759. Sin embargo, este autor, íbidem p. 760, a diferencia de lo expuesto en el texto, concluye que el principio de legalidad -como deber de hacer valer la pretensión punitiva del Estado- debe ser extendido también a los tribunales como verdaderos depositarios de la facultad-deber de castigar, donde esa declaración, como esencia de lo jurisdiccional, no es solo un poder, sino también un deber. Como explica Binder, A., Introducción al derecho procesal penal, $2^{\mathrm{a}}$ ed., Ad-Hoc, Buenos Aires, 2004, p. 316, "si bien el juez tiene poder para resolver el caso, ese poder no es un atributo personal -él encarna un poder que, en realidad, es atributo del Estado-, ni es de ejercicio optativo - no depende de su decisión juzgar o dejar de juzgar el caso". 
decidir a su arbitrio ${ }^{33}$, la no iniciación, suspensión o abandono de la persecución penal, no obstante que los antecedentes conocidos del delito y su autor permitirían iniciar la investigación y requerir la imposición de una sanción penal ${ }^{34}$. Según lo ya reflexionado, esta discrecionalidad engloba la autorización para, sin suspender, interrumpir o cesar completamente la persecución penal, promover una sanción penal devaluada

${ }^{33}$ Usamos este término en la siguiente acepción: "facultad que la ley deja a los jueces o autoridades para la apreciación de circunstancias o para la moderación de sus decisiones”, y no en aquella equivalente a "voluntad no gobernada por la razón, sino por el apetito o capricho", Diccionario de la Lengua Española de la Real Academia Española, 22a ed., 2001. Explican el antagonismo entre ambos conceptos en el ámbito administrativo García de E. y Fernández, ob. cit., pp. 485-487, aclarando que aun cuando en la discrecionalidad puede existir un margen mayor para la arbitrariedad por la posibilidad de opción que le es ínsita, arbitrariedad y discrecionalidad son conceptos antagónicos. En la arbitrariedad hay una ausencia de razones en un accionar determinado; es un simple "porque sî"; por eso la tendencia a hacerla sinónimo de falta de fundamento, de mero capricho o voluntad. En el actuar no arbitrario, en cambio, hay motivo, es decir, un antecedente de hecho y de derecho en que se funda; y hay una justificación, es decir, un proceso racional de una decisión que la explica en fundamentos objetivos. La posibilidad de optar no libera al órgano respectivo de las razones justificativas de su decisión. La determinación de esa suficiencia, consistencia y coherencia, es un tema del control de la discrecionalidad. Al respecto, nuestro TC también separa ambos conceptos con nitidez, al resolver que: "a efectos de establecer el límite entre lo arbitrario y la discrecionalidad, cabe señalar, en primer lugar, siguiendo a la doctrina, la distinción neta entre arbitrariedad y discrecionalidad, es decir, lo que es fruto de la mera voluntad o el puro capricho de lo que, por el contrario, 'cuenta con el respaldo mayor o menor, mejor o peor -es otra cuestión-, de una fundamentación que lo sostiene'” (Fernández Rodríguez, Tomás-Ramón: Discrecionalidad, Arbitrariedad y Control Jurisdiccional, Palestra Editores, $1^{a}$ edición, Lima, marzo 2006). "Así, un primer test para determinar si un enunciado normativo es o no arbitrario es si tiene o no fundamentación de algún tipo, resultando arbitrario aquello que carece de fundamento. Ya superada dicha primera barrera, corresponde calificar la legitimidad de la causa de la diferencia de trato y la legitimidad de la finalidad perseguida; para posteriormente llegar a la coherencia de ellas con los medios utilizados, y finalmente arribar al resultado buscado por el legislador”, STC Rol N 986-07 de 30.01.2008 $\left(\right.$ cons. $33^{\circ}$ ). Posteriormente la doctrina jurisprudencial de este Tribunal evoluciona hasta plantear una "discrecionalidad no arbitraria”, según la cual "el fiscal, al tener la dirección exclusiva de la investigación, puede ejercer ciertas facultades de manera discrecional. Sin embargo, esa discrecionalidad debe estar sujeta a un control que verifique que esta no se esté ejerciendo de modo arbitrario", STC Rol N $1341-09$ de 15.04.2010 (cons. $13^{\circ}$ ). Por tanto, si bien es verdad que en diversos momentos el agente público hará un uso arbitrario de una potestad discrecional, de todos modos nos interesa mantener, al menos conceptualmente, clara tal distinción para efectos de este artículo, por lo que enfatizaremos en los múltiples espacios para un no ejercicio discrecional de la persecución penal que la ley adjetiva nacional deja al MP, permitiéndole desoír el mandato de obligatoriedad que lo gobierna, más allá si tal inconducta es arbitraria o no -aunque recurrentemente lo será-.

${ }^{34}$ En similares términos, Roxin, ob. cit., p. 89, señala que el "principio de oportunidad autoriza a la Fiscalía a decidir entre la formulación de la acusación y el sobreseimiento del procedimiento, aun cuando las investigaciones conducen, con probabilidad rayana en la certeza, al resultado de que el imputado ha cometido una acción punible"; y, Maier, Derecho Procesal Argentino, ob. cit., p. 556, explica que oportunidad significa "la posibilidad de que los órganos públicos, a quienes se les encomienda la persecución penal, prescindan de ella, en presencia de la noticia de un hecho punible o, inclusive, frente a la prueba más o menos completa de su perpetración, formal o informalmente, temporal o definitivamente, condicionada o incodicionadamente, por motivos de utilidad social o razones político-criminales". Por su lado, Langbein, J., "Controlling Prosecutorial Discretion in Germany" en The University of Chicago Law Review, vol. 41, núm. 3, spring 1974, p. 440, define la discreción simplemente como el poder del Fiscal de no perseguir. 
discrecionalmente respecto de la establecida por la ley para el hecho delictuoso acreditado con los antecedentes o pruebas reunidas ${ }^{35}$.

Lo medular aquí es que la decisión de no iniciar, suspender, abandonar o degradar la persecución penal, se deja a discreción de los Fiscales del MP, es decir, no se mueve por los cauces y parámetros estrictos del derecho objetivo, sin que por tanto aquellos deban ajustarse a estándares o patrones determinados por otra autoridad, ni pueda su decisión ser revisada judicialmente en cuanto a su mérito ${ }^{36}$. Desde una óptica administrativista, estaremos entonces ante una potestad discrecional cuando el órgano pueda definir su propia política de actuación y optar, dentro del marco de la legalidad, entre diversas decisiones, todas las cuales son indiferentes para el ordenamiento y válidas ${ }^{37}$.

La cátedra europeo-continental prefiere llamar a la discrecionalidad en el ejercicio de la acción penal como "principio de oportunidad", denominación que pese haber adquirido carta de naturaleza en nuestro medio jurídico, intentaremos vadear ante la diversidad de significados que se le cuelga por la doctrina, lo que puede distraer al lector interesado ${ }^{38}$.

35 De igual parecer, Cafferata, ob. cit., pp. 32-33, para quien la atribución que confiere al MP el principio de oportunidad incluye la de limitar la persecución penal en su extensión objetiva y subjetiva, sosteniendo entre los fundamentos de este principio, el de convenir la extensión de la pena por acuerdo entre el acusador y acusado. Para Del Río, Proceso penal, consenso de las partes, ob. cit., p. 20, esta visión amplia no fue recepcionada por el ordenamiento adjetivo chileno, el que solo admitió formas restringidas que comprenden el abandono y la suspensión de la persecución en ciertos casos definidos legalmente, mas no una persecución discrecionalmente devaluada.

No viene en vano prevenir que no haremos nuestra la amplísima concepción propuesta por Berzosa, ob. cit., p. 15, del principio en comento, que parte de su contraposición al de obligatoriedad de la acción penal, por tanto, si este último significa que el órgano de la acusación está obligado a ejercitar la acción por todo hecho que revista caracteres de delito conforme a la ley, el de oportunidad debe referirse a cualquier excepción a esta obligación.

${ }^{36}$ En los términos de que se sirve Dworkin, ob. cit., pp. 84-85, la discrecionalidad del MP en el ejercicio de la acción penal, así entendida, es una discrecionalidad "fuerte". Separa este autor la discrecionalidad en un sentido "fuerte", de otros dos sentidos "débiles". En el primero, usa esa expresión para afirmar que, en lo que respecta a algún problema, el funcionario que decide no está vinculado por estándares impuestos por la autoridad en cuestión. Agrega el autor que a veces se habla de discreción en un sentido débil, para decir que por alguna razón las normas que debe aplicar un funcionario no se pueden aplicar mecánicamente, sino que exigen discernimiento. En otro sentido débil, se expresa con el término discrecionalidad que algún funcionario tiene la autoridad final para tomar una decisión que no puede ser revisada ni anulada por otro funcionario. Para Gandulfo, E., "Principios del derecho procesal penal en el nuevo sistema de procedimiento chileno", en Revista de Derecho de la Universidad Católica de Valparaíso, vol. XX, 1999, p. 426, es precisamente en ese sentido fuerte que debe tratarse el problema de la discrecionalidad del MP.

${ }^{37}$ Muñoz M., ob. cit., p. 519. En el mismo ámbito García de E. y Fernández, ob. cit., p. 461, indican que el ejercicio de las potestades discrecionales incluye, en el proceso aplicativo de la ley, una estimación subjetiva de la propia Administración con la que se completa el cuadro legal que condiciona el ejercicio de la potestad o su contenido particular.

${ }^{38}$ De la Oliva, ob. cit., pp. 20-21, reseña que "con frecuencia se entiende el principio de oportunidad con gran amplitud y vaguedad. Así entendido, engloba y significa tantas y tan diversas cosas, que, en realidad, no significa nada claro y seguro". Acostumbra, por ejemplo, engarzarse el estudio del principio de oportunidad a la delincuencia bagatelaria o de nimiedad (minima no curat praetor) -ámbito en el cual no se agota nuestra investigación-, por todos, v. Armenta, ob. cit., p. 23, que delinea el delito de bagatela como "hechos contemplados en las leyes penales, cuya reprochabilidad es escasa y cuyo bien jurídico protegido se 
La concepción de discrecionalidad que secundamos se encasilla dentro de lo conocido como "discrecionalidad política o de oportunidad", consistente en la posibilidad de ejercer la acción penal según criterios extrajurídicos, implicando por tanto un juicio de pura conveniencia en virtud del cual se decide si el ejercicio de la acción penal es apropiado respecto de ciertos objetivos políticos ${ }^{39}$. La discrecionalidad política implica a su vez una política criminal determinada, entendida esta como una estrategia global en materia de prevención, investigación, persecución y represión de la criminalidad. Mediante esta política criminal se fijarán objetivos, para cuya consecución se aprestan determinados medios. Al igual que cualquier otra política pública, la política criminal implica opciones, y estas no corresponden tan solo al momento legislativo, sino inevitablemente también al de aplicación de la ley ${ }^{40}$.

En el otro extremo de la mesa, "la discrecionalidad técnica o interpretativa" presupone una operación de valoración de hechos e interpretación de normas en virtud de la cual se decide si se está técnicamente en condiciones de ejercer la acción penal y cuál es el modo más adecuado de hacerlo ${ }^{41}$. Lo primero que tiene que apreciar el Fiscal

considera de menor relevancia”. Misma ligazón en nuestra doctrina se aprecia, v.gr., en Maturana y Montero, ob. cit., T. I, p. 575; y, Otero L., M., "El principio de oportunidad y salidas alternativas", en Revista de Derecho Procesal, núm. 20, 2005, p. 298. Nuestra posición no implica preterir que la incorporación del principio de oportunidad en diferentes ordenamientos jurídicos del ámbito europeo-continental tuvo como una de sus razones principales la necesidad de hacer frente al aumento de la pequeña y mediana criminalidad, la que, en el caso particular de Alemania, se hizo imposible de contener y enjuiciar luego de la desastrosa situación económica y social en que varó esa nación tras las dos guerras mundiales, cfr. Berzosa, ob. cit., pp. 13-14, y, Armenta, ob. cit., p. 56.

39 Diez-Picazo, ob. cit., p. 15. La distinción entre la discrecionalidad política y técnica que realiza el autor guarda similitud con la homónima gestada por la doctrina administrativista, cfr. Sánchez M., M., Discrecionalidad administrativa y control judicial, Tecnos, Madrid, 1994, pp. 127 y ss, para quien la discrecionalidad política stricto sensu "se halla en todos aquellos supuestos en que la ley otorga, expresado implícitamente, un margen de libertad a los órganos gubernativos para que valoren los aspectos y las consecuencias políticas de sus decisiones", mientras la discrecionalidad técnica se refiere a "aquellos casos en que la ley confiere un ámbito de decisión a los administradores para obtener un resultado conforme a evaluaciones de naturaleza exclusivamente técnica"; Muñoz M., ob. cit., pp. 523-524, deslinda estos conceptos de la siguiente forma: la oportunidad política es la discrecionalidad para la adopción de políticas siempre disponible al legislador y solo excepcionalmente la Administración, en cambio, la discrecionalidad jurídica es la que usan siempre los jueces y tribunales cuando, al interpretar las normas, tienen que crear decisiones que les sirvan para resolver los casos que tienen planteados; Betti, E., "Interpretación de la ley y de los actos jurídicos”, Editorial Revista de Derecho Privado, Madrid, 1971, pp. 143-145 y ss., distingue la discrecionalidad administrativa o pura de la discrecionalidad de carácter supletorio o complementario. En la primera, precede, al efecto de determinar preliminarmente los límites y las directrices impuestas al poder discrecional, una interpretación, aunque de segundo grado, que se extiende a la investigación de los fines de la ley, pero a ella sigue una ulterior apreciación para actuar según los criterios de conveniencia y oportunidad, tanto de los intereses concurrentes como de las varias líneas de conducta posibles para la solución de su conflicto. La discrecionalidad de carácter supletorio o complementario, por el contrario, está al servicio de la adaptación y de la especificación de la norma a la variabilidad de los tipos en función de la determinación y apreciación del supuesto concreto, donde tiene lugar en realidad una apreciación vinculada que presenta el carácter de interpretación y es propia de la función jurisdiccional.

${ }^{40}$ Diez-Picazo, ob. cit., p. 27.

${ }^{41}$ Diez-Picazo, ob. cit., p. 15 
(mediante una calificación jurídica) es si el hecho es constitutivo de delito, pues la acción solo procede cuando lo sea. Ha de considerar después si puede aportar al menos indicios racionales de que se haya perpetrado, y sobre todo, si existen motivos suficientes para acusar a determinada persona; en suma, si la prueba del factum y de la participación del inculpado aparece como posible, y aun (en un momento ulterior) como probable. Pues en otro caso la acusación no tiene base, y sería antijurídica ${ }^{42}$.

En una primera aproximación, pareciera de cuanto se ha intentado explicar claramente distinguible el problema de la fundamentación de la acción por un lado, de la oportunidad de la acción fundada, por el otro. En lo que hemos abarcado por la expresión "discrecionalidad técnica" se trataría en realidad de un asunto de "procedencia" de la acción penal, pero no de discrecionalidad en el sentido de oportunidad ${ }^{43}$. La discrecionalidad técnica es un elemento inherente al ejercicio de la acción penal del cual no puede abstraerse, a diferencia de la discrecionalidad política, que aun cuando no suprimida, sí puede ser al menos fuertemente restringida ${ }^{44}$.

No obstante la aparente simplicidad conceptual de esta delimitación, al depender el ejercicio de la acción penal de una valoración del MP, si esta se lleva a cabo equivocadamente al estimar que el hecho imputado no constituye delito o que constituye un delito de menor penalidad al que jurídicamente corresponde, puede en último término impedirse por el acusador estatal la persecución de un delito así como la imposición de la pena establecida en la ley si el legislador no ha previsto remedios efectivos para ello. De ahí que comprendamos en este estudio como ejercicio -o no ejercicio más biendiscrecional de la acción penal, aquellas situaciones en las que la ley no ha autorizado expresamente al MP a abandonar, suspender o degradar la persecución penal a base de criterios de oportunidad o conveniencia, pero sin embargo, de hacerlo, no se ha otorgado el andamiaje jurídico al órgano jurisdiccional para su enmienda. De consiguiente, los manidos conceptos de "oportunidad reglada" y "oportunidad libre" resultarán de escasa utilidad si más allá de las previsiones legales de los casos y condiciones en los que el MP puede abstenerse de la persecución, no se ha contemplado remedio procesal cierto y efectivo frente a su desconocimiento o exceso por parte del MP, pues su ausencia tornará difusa la línea que dibuja los contornos de ambos tipos de oportunidad. Únicamente una "concepción dinámica de la discrecionalidad", que no pierda de vista la actitud de los Tribunales frente a las actuaciones del MP, nos ofrecerá una visión acabada y global de nuestro sistema procesal ${ }^{45}$.

\footnotetext{
42 Gómez O. y Herce Q., ob. cit., pp. 97-98.

43 Gómez O., E., Comentarios a la Ley de Enjuiciamiento Criminal, T.II, Bosch, Barcelona, 1947-1951,
} p. 528 .

${ }^{44}$ Diez-Picazo, ob. cit., p. 15.

${ }^{45}$ Esta perspectiva dinámica de la discrecionalidad no atiende solo al modo en que el legislador configura las potestades administrativas (concepción estática de la legalidad que procede directamente de M. Hariou), sino que hace depender la autonomía de la decisión administrativa de lo que resuelvan los Tribunales al enjuiciarla, Muñoz M., ob. cit., p. 522. La conversión en una obligación natural de actuar dentro de legalidad que propone Sainz M., F. Conceptos Jurídicos, interpretación y discrecionalidad administrativa, Civitas, Madrid, 1976, p. 303, respecto de aquella potestad no controlada judicialmente por opción legislativa, sin duda 


\section{PRinCiPio de Obligatoriedad de la ACCIÓN PENAL EN EL SISTEMA PROCESAL PENAL CHILENO}

Pese a su tradición procesal-penal legalista, retribucionista e inquisitoria ${ }^{46}$, no hay normas constitucionales en el ordenamiento nacional que acojan el principio de obligatoriedad de la acción penal o que prohíban o excluyan el de discrecionalidad en su ejercicio ${ }^{47}$. El art. 83 de nuestra Carta Fundamental mandata al MP el ejercicio de la acción penal pública "en la forma prevista por la ley", encargando al legislador determinar los márgenes de discrecionalidad con los que ese órgano desarrollará su labor persecutoria.

Al recoger nuestro sistema a nivel meramente legal el principio de obligatoriedad de la acción penal, le priva de la innegable fuerza expansiva de que gozan los preceptos constitucionales a la hora de interpretar las disposiciones dictadas por el legislador, pues de haber optado por su recepción en el texto constitucional, sería inevitable la exégesis a la luz de la misma, por ejemplo, de todo el estatuto del $\mathrm{MP}^{48}$.

El MP, sus titulares e integrantes, como los de cualquier otro órgano del Estado, están entonces sometidos al principio de legalidad o juridicidad, consagrado en los arts. $6^{\circ}$ y $7^{\circ}$ de nuestra CPR, por el cual los órganos del Estado deben actuar según la Constitución y la ley, legalmente investidos y dentro de su competencia, de modo que los actos que

que más allá de su ingenio teórico, no evitará la incorporación por el Fiscal de criterios de oportunidad y conveniencia en su actuación que justifiquen calificarla como discrecional. Así las cosas, más ventajoso, por su realismo y pragmatismo, resulta seguir a Davis, K.C., Discretionary Justice. A preliminary inquiry, Baton Rouge, Louisiana State University Press, 1969, p. 4, quien postula que los elementos que deben ser tomados en cuenta en el concepto de discrecionalidad, incluyen, primero, que la discrecionalidad no se limita a lo que ha sido autorizado o es legal, sino que incluye todo lo que se encuentra dentro de los límites efectivos del poder del funcionario; segundo, que comprende también la elección de no hacer nada; y tercero, que la discrecionalidad no se ejerce solo en la resolución final de los casos o problemas sino también en un volumen bastante más numeroso de decisiones intermedias. Rosett, A., "Discretion, Severity and Legality in Criminal Justice", en S. Cal. L. Rev., vol. 46, 1972-1973, p. 15-16, ahondando en esta concepción, precisa que la discrecionalidad no es solo ausencia de estándares de control sustantivos y, en un sentido procesal, puede significar que el proceso usado para alcanzar la decisión es informal y provee oportunidades para una desviación incontrolada de la norma que gobierna el caso. Da como ejemplo la jury nullification, donde el jurado suele ignorar las instrucciones del juez y absolver a un acusado aparentemente culpable, lo que se produce no por la ausencia de regla que gobierne la decisión del jurado, pues en la mayoría de los casos sus integrantes son exhaustivamente instruidos sobre la ley por el juez, ni tampoco por alguna norma que les permita ignorar esas reglas, sino que el factor clave está en que la sala del jurado está fuera del escrutinio y de la formalidad de la sala de la corte. Vorenberg, J., "Narrowing the Discretion of Criminal Justice Officials", en Duke L.J., vol. 1976, núm. 4, Sep. 1976, p. 653-654, por su lado, sigue una concepción aún más difusa, indicando que la discrecionalidad puede mejor ser vista como un concepto residual, como el espacio dejado para juicios subjetivos por los estatutos, reglas administrativas, decisiones judiciales, patrones sociales y presiones institucionales que pesan sobre la decisión oficial.

46 Esta evaluación corresponde a Couso S., ob. cit., p. 183.

${ }^{47} \mathrm{Al}$ igual que la Constituciones de Alemania y de la Nación Argentina. Otros textos constitucionales expresamente imponen la obligación de ejercer la acción penal, como el art. 112 de la Constitución italiana.

${ }^{48}$ Diez-Picazo, ob. cit., p. 14. 
efectúen en contravención a esta regla son nulos y de ningún valor ${ }^{49}$. Una especificación de dicho principio general es el de legalidad procesal en cuanto regula las precisas potestades y funciones del MP en la investigación y en el proceso penal, y ordena que los fiscales ejerzan y sustenten la acción penal pública "en la forma prevista por la ley" (art. 83 CPR y 77 CPP). Pues bien, nuestro ordenamiento legal, y por tanto de acuerdo al principio de legalidad procesal, da cabida tanto al principio de obligatoriedad como de discrecionalidad de la acción penal, el primero nada más como máxima general de actuación del MP, pudiendo este suspender, interrumpir o hacer cesar la persecución penal en los casos previstos por la ley (art. 166 CPP). Dentro de estos supuestos tipificados en la ley, se suele incluir por nuestra cátedra como manifestaciones de oportunidad reglada a la oportunidad estricta (art. $170 \mathrm{CPP}$ ) la suspensión condicional del procedimiento (art. 237 CPP) y el acuerdo reparatorio (art. $241 \mathrm{CPP}$ ), que autorizan nada más que la suspensión o abandono de la acción penal ${ }^{50}$. Sin embargo, creemos que una mirada más comprensiva de nuestro proceso penal pone en evidencia una diversidad de otros espacios en la regulación adjetiva penal, que permiten también al fiscal abandonar o suspender la persecución discrecionalmente, e incluso atenuar el rigor de la persecución penal por la que se haya decidido ${ }^{51}$.

Es así como puede advertirse esta deficiente regulación, entre otros tantos aspectos -no pretendemos aquí una enunciación exhaustiva-, en materia de archivo provisional (art. $167 \mathrm{CPP}$ ), donde solo se prevé un control a posteriori de la decisión del Fiscal impulsado por la víctima, a quien se impone para ello la carga de presentar querella; en materia de formalización, la imposibilidad de forzar al MP para que formule cargos

${ }^{49}$ Sobre el principio de juridicidad o legalidad en la normativa constitucional nacional, v. Cea E., J.L., Derecho Constitucional Chileno, T. I, $2^{a}$ ed., Ed. Universidad Católica de Chile, 2008, pp. 248 y ss. Ruiz V., Estudios de Derecho procesal penal, ob. cit., p. 74, reputa una obviedad asignar al Ministerio Fiscal la exigencia de legalidad (art. 124.1 Const. española), atendido el sometimiento pleno de la Administración Pública a la ley y al Derecho. Sin embargo, el autor tacha de acertada su expresa incorporación por la especial connotación que tiene el principio de legalidad referido al MP, por el cual debe también promover la acción de la justicia en defensa de la legalidad, impidiendo, mediante los Tribunales, que otros actúen ilegalmente, sobre todo en el campo penal. Sobre el sometimiento del MP chileno al principio de legalidad, v. Carocca P., A., El Nuevo Sistema Procesal Penal, $3^{\text {a }}$ ed., LexisNexis, Santiago, 2005, pp. 24 y ss.

50 Maturana y Montero, ob. cit., T. I, pp. 112-113, recogen como manifestaciones del principio de oportunidad reglada solo estos tres institutos procesales, aunque añaden como excepciones al principio de legalidad el archivo provisional (art. 167 CPP), el no inicio de la investigación (art. 168 CPP), y la decisión de no perseverar en la investigación (art. 248.c CPP), íbidem p. 339. En regla con lo antes expuesto, es que alguna doctrina afirma que tales mecanismos "no son más que especiales formas de aplicación de la legalidad, ya que es la propia ley la que con detalle establece quiénes, cómo, cuándo, hasta qué límite, bajo qué controles y en qué supuesto se aplican”, Del Río, Proceso penal, consenso de las partes, ob. cit., p. 73.

${ }^{51}$ Para Del Río, El principio del consenso de las partes, ob. cit., p. 161, una forma más amplia y extensiva de entender el principio de oportunidad comprende toda forma o manifestación de no legalidad, ya no solo referido al no ejercicio de la acción penal, sino también respecto del procedimiento de sustanciación del asunto penal, tanto como al objeto procesal y penal sustantivo. Para este autor, ídem pp. 162-163, el prescindir de hechos relevantes o la introducción de hechos no acreditados o el pacto de una calificación jurídica improcedente constituye una excepción al sometimiento a la legalidad penal sustantiva, excediendo el obligatorio ejercicio de la acción penal que impone al MP la legalidad procesal. 
no obstante existir antecedentes investigativos que lo justifiquen ${ }^{52}$, o que lo haga de manera completa cuando omite circunstancias fácticas relevantes para la calificación del hecho; la decisión de no perseverar en el procedimiento (art. 248 c) CPP) no es revisable jurisdiccionalmente en cuanto a su mérito ${ }^{53}$, y el forzamiento de la acusación (art. 258 CPP) que puede intentar el querellante, se ve comúnmente obstaculizado frente a la exigencia jurisprudencial de formalización previa ${ }^{54}$-esto último también sucede frente a una solicitud de sobreseimiento de la causa-; y desde luego, la antojadiza manipulación de los hechos como de su calificación en los procedimientos simplificados de resolución inmediata (art. 395 CPP) y abreviado (art. 407 CPP), como dudosas herramientas de negociación con la defensa e imputado para obtener de este su renuncia al juicio oral ${ }^{55}$.

En lo que dice relación a los procedimientos especiales en que se introduce el carácter consensual en el ámbito penal, la ley solo ha dotado al juez en el procedimiento abreviado de limitadas herramientas para reprimir o acotar tales prácticas, herramientas que en todo caso deben ponerse en práctica cuidando no afectar el carácter acusatorio

52 Admite esta imposibilidad de forzamiento Piedrabuena, G. Control judicial anterior a la formalización de la investigación (Artículo 186 del C.P.P.). [en línea] < http://www.cde.cl/wps/wcm/connect/37619281-b7ff4923-aa67-ba43abd267c0/Rev+23_5+control + judicial+anterior +a+la+formalizacion + de+la+investigacion. pdf?MOD=AJPERES > [consulta: 21 noviembre 2012], pp. 9-38. Reconociendo tal traba como acorde al diseño de nuestro proceso penal, v. Herrera, M. "Control judicial previo a la formalización de la investigación. Las posibles sanciones ante la inobservancia del plazo", en Revista de Derecho de la Pontificia Universidad Católica de Valparaíso, XXVI, p. 403; y, Bordalí, La acción penal, ob. cit., p. 540. v.t. Castro, C. Resabios Inquisitivos en el Proceso Penal Chileno, Metropolitana, Santiago, 2010, pp. 219 y ss., y, Fernández, M.Á. La nueva justicia penal frente a la Constitución, LexisNexis, Santiago, 2006, p. 206. De manera aislada en nuestra cátedra, Cerda y Hermosilla, ob. cit., pp. 209-210, estiman que el mecanismo del art. 186 CPP opera también respecto de terceros no intervinientes que ven afectado el ejercicio de sus derechos constitucionales, con dudas si incluye o no a la víctima, y Aguilera, La participación, ob. cit., p. 67, considera la facultad de instar a la formalización como conciliable con el rol accesorio de la víctima en el proceso penal.

53 cfr. Aguilar, C. Manual de Derecho Procesal Penal Oral, Metropolitana, Santiago, T. I, 2004, p. 413; Novoa, J.P. “Análisis de la facultad del Ministerio Público de no perseverar en la investigación”, en Revista procesal penal, 2004, No 27, pp. 23-24; Maturana, C. "El Sobreseimiento", en Revista de Derecho Procesal, 2005, N 20, p. 357; Fernández, ob. cit., p. 206; Cerda y Hermosilla, ob. cit., p. 313; y, Horvitz y López, ob. cit., T. I, p. 585, quienes afirman que "la decisión sobre el mérito de los antecedentes de la investigación es, pues, de exclusiva competencia del Ministerio Público y no cabe, en consecuencia, un pronunciamiento ulterior del juez ni, evidentemente, recursos jurisdiccionales en contra de la misma”. v.t. SCA de Rancagua Rol N ${ }^{\circ}$ 183-2009 de 02.07.2009 al decidir que: “(---) siendo además esta facultad de carácter privativo y excluyente, de modo que el juez de Garantía no puede resolver no aprobar la decisión del Ministerio Público”.

${ }^{54} \mathrm{El}$ TC reiteradamente invoca en sus argumentaciones la necesidad de la formalización previo al cierre de la investigación y posterior acusación, v.gr., SSTC Rol N $815-2007$ de 19.08.2008 (cons. $36^{\circ}$ ), Rol N ${ }^{\circ}$ 1337-2009 de 20.8.2009, voto de prevención (cons. 6º, Rol No 1380-2009 de 03.11.2009 (cons. $17^{\circ}$ ), Rol No $1542-2009$ de 31.08.2010 (cons. $6^{\circ}$ ), y, Rol No $1484-2009$ de 5.10.2010 (cons. $17^{\circ}$ ). Ha seguido también el mismo criterio nuestros tribunales superiores en SCS Rol N ${ }^{\circ}$ 6742-2008 de 26.02.2009, SSCA Sn. Miguel Rol No 1249-2006 de 17.11.2006, y Rol No 26-2011 de 04.03.2011; SSCA Stgo. Rol N ${ }^{\circ} 286-$ 2008 de 17.03.2008 y Rol No 658-2008 de 07.05.2008; SCA Rancagua Rol No 282-2012 de 23.07.2012; y, SJG $4^{\circ}$ Stgo. RUC N $0600029209-3$ de 16.10.2006. Piedrabuena, Jurisprudencia, ob. cit., pp. 85-86, señala que la mayoría de los jueces de Santiago está aceptando el forzamiento de la acusación no obstante que el Fiscal se haya resistido a formalizar, pero sin citar sus fuentes.

55 Del Río, Proceso penal, consenso de las partes, ob. cit. 
del proceso, en otras palabras, que el juez no asuma en los hechos el papel de acusador que el Fiscal ha desarrollado negligentemente. Todo esto empeora en el procedimiento simplificado de resolución inmediata, en el que ni siquiera se contempla algún precepto al cual echar mano para que el órgano jurisdiccional efectúe un control previo como el que se dispone en el procedimiento abreviado, con la consiguiente inacción de nuestros Tribunales.

Estos puntos y otros tantos otros, cuyo desarrollo particular demanda un trabajo y esfuerzo anexo, nos permiten ya aproximarnos de mejor forma a la verdadera fisonomía de nuestro proceso penal, donde contrariamente a las miradas globalizantes y distantes que proclaman un general apego al principio de obligatoriedad de la acción penal en nuestro proceso - con escaso campo para una oportunidad reglada-, lo cierto es que un agudo acercamiento nos entregará un panorama muy diverso, colmado de espacios para la discrecionalidad política del órgano público de persecución. Frente a ello, el primer paso es reconocer tal configuración, y luego definir institucional y políticamente si es la más conveniente al sistema de justicia criminal a que aspiramos, manteniéndola, o incluso potenciándola, o muy por el contrario, reconocerla como el producto de una defectuosa regulación, y coherentemente, abocarse a su modificación y corrección.

\section{Conclusiones}

1. Por obligatoriedad de la acción penal entendemos el deber del MP de iniciar, sostener y perseverar en la persecución penal de todo delito del cual tome conocimiento, sin que pueda suspenderla, interrumpirla o hacerla cesar a su discreción.

2. La investigación y la acusación formuladas en virtud del principio de obligatoriedad, están enlazadas a la legalidad sustantiva porque la delimitación del hecho que constituirá el objeto del juicio solo puede realizarse teniendo como referencia lo que la ley sustantiva establece como delito -y circunstancias modificativas-, atendido el carácter fragmentario del derecho penal, debiendo en consecuencia requerirse la sanción anunciada previamente por el legislador para ese hecho delictivo y no otro.

3. Con el término discrecionalidad apuntamos a la autorización legal dada al MP para decidir a su discreción, la no iniciación, suspensión o abandono de la persecución penal, no obstante que los antecedentes conocidos del delito y su autor permitirían iniciar la investigación y requerir la imposición de una sanción penal. Esta discrecionalidad engloba la autorización para promover una sanción penal devaluada respecto de la establecida por la ley para el hecho delictuoso acreditado con los antecedentes reunidos.

4. Esta concepción de discrecionalidad se encasilla dentro de la "discrecionalidad política o de oportunidad", consistente en la posibilidad de ejercer la acción penal según criterios extrajurídicos, implicando por tanto un juicio de pura conveniencia.

5. La distinción entre oportunidad reglada y libre resultarán de escasa utilidad si más allá de las previsiones legales de los casos y condiciones en los que el MP puede 
abstenerse de la persecución, no se ha contemplado remedio procesal cierto y efectivo frente a su desconocimiento o exceso por parte del MP.

6. Con el principio de obligatoriedad el MP se somete exclusivamente a la ley penal, tanto a la procesal que regula sus competencias y potestades en la persecución y en el proceso como a la sustantiva que debe observar al hacer sus postulaciones, mientras que con el principio de discrecionalidad el MP está sometido exclusivamente a la ley que regula sus competencias y potestades, pero estas mismas normas lo autorizan para sustraerse con mayor o menor amplitud, y mayor o menor control judicial, a la ley penal sustantiva al momento de promover la acción penal, e incorporar criterios de oportunidad en su dictamen.

7. Ambas, discrecionalidad y obligatoriedad, tienen un mismo campo de acción, esto es, las facultades y límites de los poderes públicos, ya que vienen siempre referidos al Fiscal y/o al Juez, así como a las funciones que uno y otro desempeñan en el proceso penal.

8. No hay total identidad entre el principio de obligatoriedad de la acción penal y el de legalidad sustantiva. Este constituye un cerco normativo al ius puniendi estatal, del cual no se desprende una formulación positiva que obstaculice incorporar legislativamente el principio de discrecionalidad u oportunidad.

9. El ordenamiento constitucional nacional no acoge el principio de obligatoriedad de la acción penal ni prohíbe o excluye el de discrecionalidad en su ejercicio. El art. 83 de la CPR mandata al MP el ejercicio de la acción penal pública "en la forma prevista por la ley”, encargando al legislador determinar los márgenes de discrecionalidad con los que ese órgano desarrollará su labor persecutoria.

10. En el proceso penal nacional se advierten numerosos espacios de discrecionalidad política del órgano público de persecución. Frente a ello, debe reconocerse tal configuración -haya sido planeada o no por el legislador-, y luego definir institucional y políticamente si es el sistema de justicia criminal más conveniente para nuestra comunidad, manteniéndola, o incluso potenciándola, o muy por el contrario, reconocerla como el producto de una defectuosa regulación, y coherentemente, avocarse a su modificación y corrección.

\section{BiBLIOGRAFÍA}

Aguilar, C., Manual de Derecho Procesal Penal Oral, Metropolitana, Santiago, T.I, 2004.

Aguilera, D., "La participación de la víctima en la persecución penal oficial. Análisis a partir de la jurisprudencia del Tribunal Constitucional”, en Revista de Derecho Universidad Católica del Norte, Sección: Estudios, Año 18, No 2, 2011, pp. 51-72.

Aguilera, E., El "principio de consenso". La conformidad en el Proceso Penal Español, $1^{\text {a }}$ ed., Cedecs, Barcelona, 1998.

Alarcón J., P., Discrecionalidad Administrativa. Un estudio de la jurisprudencia chilena, LexisNexis, Santiago, 2000.

Alschuler, A., "Jury: Legal Aspects", en AAVV, Encyclopedia of Crime E Justice, vol. 2, 2ª ed., Macmillan Reference USA, New York, 2002, pp. 870-883. 
Andrés I., P., "El Ministerio Fiscal entre 'viejo' y 'nuevo' proceso”, en Revista de Ciencias Penales, No especial Ministerio Público, 1990-1993.

Andrés I., P., "Por un Ministerio Público 'dentro de la legalidad'”, en Nueva Doctrina Penal, 1998/B, Editores del Puerto, Buenos Aires, 1998.

Armenta D., T., Criminalidad de bagatela y principio de oportunidad: Alemania y España, PPU, Barcelona, 1991.

Asencio M., J.M., Principio Acusatorio y Derecho de Defensa en el Proceso Penal, $1^{\text {a }}$ ed., Trivium, Madrid, 1991.

Barros, L., Frühling, H., García, G., Quintana, A. y Sánchez, D., "El proceso penal chileno y su protección de los derechos del imputado", en Proceso Penal y Derechos Fundamentales.

CoLECCIÓN Estudios, N 1, Corporación Nacional de Reparación y Reconciliación, Santiago, 1994, pp. 47-179.

Berzosa, $\mathrm{M}^{\mathrm{a}} \mathrm{V}$, "Los principios de legalidad y oportunidad en el proceso penal", en Picó I Junoy, J. (Dir.), Problemas actuales de la Justicia Penal, Bosch, Barcelona, 2001, pp. 13-24.

Betti, E., "Interpretación de la ley y de los actos jurídicos", Editorial Revista de Derecho Privado, Madrid, 1971.

Bettiol, G., Instituciones de derecho penal y procesal, Bosch, Barcelona, 1977.

Binder, A., Introducción al derecho procesal penal, $2^{\mathrm{a}}$ ed., Ad-Hoc, Buenos Aires, 2004.

Bordalí, A., "No Hay Ejercicio del Derecho Fundamental de Acción en el Proceso Penal. Sentencia del Tribunal Constitucional que Declaró Inaplicable el Artículo 230 del Código Procesal Penal”, en Revista de Derecho, Universidad Austral, vol. XXI, núm. 2, diciembre 2008, pp. 205-249.

Bordalí, A., "La acción penal y la víctima en el Derecho chileno", en Revista de Derecho, Pontificia Universidad Católica de Valparaíso, vol. XXXVII, 2 sem. 2011, pp. 513-545.

Bordalí, A., "Análisis crítico de la jurisprudencia del tribunal constitucional sobre el derecho a la tutela judicial", en Revista Chilena de Derecho, vol. 38 N 2, 2011, pp. 311-337.

Bovino, A., Problemas del derecho procesal penal contemporáneo, Editores del Puerto, Buenos Aires, 1998.

Bullemore, V. y Mackinnon, J., Curso de Derecho Penal. Parte General, T.I., 1ª ed., LexisNexis, Santiago, 2005.

Bustos, J., González, F., Riego, C., Jiménez, M.A., Vargas, J.E. y Horvitz, M.I., "El proceso penal chileno", en Corporación Nacional de Reparación y Reconciliación, Proceso Penal y Derechos Fundamentales. Colección Estudios, N 1, Santiago, 1994.

Bustos, J. y Hormazábal, H., Lecciones de Derecho Penal, vol. I., Trotta, Madrid, 1997.

Bustos, J., Derecho Penal. Parte General, T.I., 2a ed., Ediciones Jurídicas de Santiago, Santiago, 2007.

Cafferata N., J., Cuestiones actuales sobre el proceso penal, $3^{\mathrm{a}}$ ed., Editores del Puerto, Buenos Aires, 2000.

Carocca P., A., El Nuevo Sistema Procesal Penal, $3^{\mathrm{a}}$ ed., LexisNexis, Santiago, 2005.

Castro, C., Resabios Inquisitivos en el Proceso Penal Chileno, Metropolitana, Santiago, 2010.

Cea E., J.L., Derecho Constitucional Chileno, T. I, $2^{\mathrm{a}}$ ed., Ed. Universidad Católica de Chile, 2008.

Cerda, R. y Hermosilla, F., El Código Procesal Penal. Comentarios, Concordancias y Jurisprudencia, $2^{a}$ ed., Librotecnia, Santiago, 2006.

Clariá O., J., Derecho Procesal Penal, T.I, Rubinzal-Culzoni, Buenos Aires.

Cobo del Rosal, M. y Vives Antón, T., Derecho Penal. Parte General, 4ª ed., Tirant lo Blanch, Valencia, 1996.

Conde-PumPIDO, C., "El principio de oportunidad reglada: su posible incorporación al sistema del proceso penal español", en AAVV, La Reforma del Proceso Penal. II Congreso de Derecho Procesal de Castilla y León. Ministerio de Justicia, Madrid, 1989, pp. 287-308.

Couso S., J., "Oportunidad versus legalidad: entre economía político-criminal, despenalización, prevención y principios garantistas”, en Cuadernos de análisis jurídico, núm. 39, 1998, pp. 183-195. 
Davis, K.C., Discretionary Justice. A preliminary inquiry, Baton Rouge, Louisiana State University Press, 1969.

De Diego Díez, L.A., La conformidad del acusado, Tirant lo Blanch, Valencia, 1997.

De la Oliva, A., Aragoneses, S., Hinojosa, Rafael, Muerza, J. y Tomé, J.A., Derecho Procesal Penal, $4^{a}$ ed. Centro de Estudios Areces S.A., Madrid, 1999.

Delgado, J., "El principio de oportunidad en el proceso penal", en AAVV, La Reforma del Proceso Penal. II Congreso de Derecho Procesal de Castilla y León, Ministerio de Justicia, Madrid, 1989, pp. 309-319.

Del Río F., C., "El principio del consenso de las partes en el proceso penal y enjuiciamiento jurisdiccional: aclaraciones conceptuales necesarias", Revista Chilena de Derecho, vol. 35, núm. 1, 2008, pp. 157-182.

Del Río F., C., Proceso penal, consenso de las partes y enjuiciamiento jurisdiccional, Librotecnia, Santiago, 2009.

Diez-Picazo, L.M., El poder de acusar, Ministerio Fiscal y Constitucionalismo, Ariel, Barcelona, 2000.

Duce, M. y Riego, C., Proceso Penal, Editorial Jurídica de Chile, Santiago, 2009.

Dworkin, R., Los derechos en serio, $4^{\mathrm{a}}$ reimp., Ariel, Barcelona, 1999.

Fernández, M.Á. La nueva justicia penal frente a la Constitución, LexisNexis, Santiago, 2006.

Ferrajoli, L., Derecho y razón. Teoría del garantismo penal, $5^{\text {a }}$ ed., Trotta, Madrid, 2001.

García de Enterría, E. y Fernández, T.R., Curso de Derecho Administrativo I, $12^{\mathrm{a}}$ ed., ThomsonCivitas, Madrid, 2004.

Garrido M., M., Derecho Penal. Parte General, T.I., 1ª ed., Editorial Jurídica de Chile, Santiago, 2001.

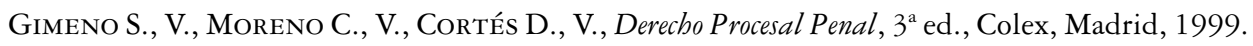

Gómez C., J.L., El proceso penal alemán. Introducción y normas básicas, $1^{\mathrm{a}}$ ed., Bosch, Barcelona, 1985.

Gómez O., E., Comentarios a la Ley de Enjuiciamiento Criminal, T.II, Bosch, Barcelona, 1947-1951.

Gómez O., E. y Herce Q., V., Derecho Procesal Penal, $10^{\mathrm{a}}$ ed., Artes Gráficas y Ediciones, Madrid.

Hassemer, W., "La persecución penal: legalidad y oportunidad", en Jueces para la democracia, núm. 4, 1988, pp. 8-11.

Jiménez de Asúa, L., Principios de Derecho Penal. La Ley y el Delito, Abeledo-Perrot, Buenos Aires.

Lafave, W., Israel, J., King, N. y Kerr, O., Criminal Procedure, $5^{a}$ ed., West, 2009.

López, J. y Horvitz, M.I., Derecho Procesal Penal Chileno, T.I, Jurídica de Chile, Santiago, 2005.

Maier, J., Derecho Procesal Penal Argentino, T.I., vol. B, Hammurabi, Buenos Aires, 1989.

Maier, J., Derecho Procesal Penal. II. Parte General. Sujetos procesales, $1^{\mathrm{a}}$ ed., Editores del Puerto, Buenos Aires, 2003.

Maturana, C. "El Sobreseimiento", en Revista de Derecho Procesal, 2005, No 20, pp. 337-367.

Maturana C. y Montero, R., Derecho Procesal Penal, T.I, Legal Publishing, Santiago, 2010.

Mera, J., "Comentario de Jorge Mera", en AAVV, El Ministerio Público para una nueva justicia criminal, Fundación Paz Ciudadana, Escuela de Derecho Universidad Diego Portales, Corporación de Promoción Universitaria, Santiago, 1994, pp. 165-169.

Mera, J., Derechos Humanos en el Derecho Penal Chileno, Conosur, Santiago, 1998.

Montero, J., Ortells, M. y Gómez, J., Derecho Jurisdiccional. Parte General, I. $2^{\text {a }}$ ed., Bosch, Barcelona, 1989.

Montero, J., Gómez, J., Ortells, M. y Monton R., A., Derecho Jurisdiccional, Proceso Penal, III, Bosch, Barcelona, 1991.

MuÑoz C., F., Introducción al Derecho Penal, B de F, Buenos Aires, 2001.

Muñoz M., S., Tratado de Derecho Administrativo y Derecho Público General, T.I, $1^{\mathrm{a}}$ ed., ThomsonCivitas, Madrid, 2004. 
Náquira, J., Izquierdo, C., Vial, P. y Vidal, V., "Principios y penas en el derecho penal chileno", en Revista Electrónica de Ciencia Penal y Criminología, núm. 10-r2 (2008), http:// criminet.ugr.es/recpc (fecha consulta: 10-12-2011).

NovoA, J.P., “Análisis de la Facultad del Ministerio Público de no perseverar en la investigación”, en Revista procesal penal, 2004, No 27 , pp. 23-34.

Núñez, J.C., Tratado del Proceso Penal y del Juicio Oral, T. I, Editorial Jurídica de Chile, Santiago, 2003.

Ortells R., M., "Cuatro aproximaciones al nuevo proceso penal chileno desde la perspectiva del proceso penal en países de la Unión Europea”, en AAVV, El Nuevo Proceso Penal Chileno, Facultad de Ciencias Jurídicas y Sociales. Depto. de Derecho Procesal. Universidad de Concepción, 2000, pp. 307-344.

Otero L., M., "El principio de oportunidad y salidas alternativas", en Revista de Derecho Procesal, núm. 20, 2005, pp. 57-99.

Perazzo, P., "La acción en el Nuevo Proceso Penal”, en Revista de Derecho Procesal, núm. 20, 2005, pp. 257-268.

Piedrabuena, G., "Rol del Ministerio Público en el nuevo proceso penal”, en Revista Chilena de Derecho, vol. 30, núm. 1, Sección Estudios, 2003, pp. 11-21.

Piedrabuena, G., "Jurisprudencia del Tribunal Constitucional sobre normas del Código Procesal Penal”, en Revista de derecho. Consejo de Defensa del Estado, núm. 21, jun. 2009, pp. 69-94.

Piedrabuena, G., Control Judicial anterior a la formalización de la investigación (Artículo 186 del C.P.P.). [en línea] <http://www.cde.cl/wps/wcm/connect/37619281-b7ff-4923-aa67-ba43ab$\mathrm{d} 267 \mathrm{c} 0 / \mathrm{Rev}+23 \_5+$ control + judicial + anterior $+\mathrm{a}+\mathrm{la}+$ formalizacion $+\mathrm{de}+\mathrm{la}+$ investigacion. pdf?MOD=AJPERES > [consulta: 21 noviembre 2011], pp. 9-38.

Pierry A., P., "El control de la discrecionalidad administrativa", en Revista Chilena de Derecho, vol. 11, 1984, pp. 479-491.

Prada, J., "España”, en Maciá, R., Sistemas de Proceso Penal en Europa, Cedecs, Barcelona, 1998, pp. 91-124.

Prieto-Castro, L. y Gutiérrez de C., E., Derecho Procesal Penal, 2a ed., Tecnos, Madrid, 1982.

Quintero, G., y Morales, F., y Prats, M., Curso de Derecho Penal. Parte General (Acorde al Nuevo Código Penal de 1995), Cedecs, Barcelona, 1996.

Rico, J.M., Justicia penal y transición democrática en América Latina, Siglo Veintiuno editores, México, 1997.

Rodríguez, N., La justicia penal negociada. Experiencias de derecho comparado, Ediciones Universidad Salamanca, Salamanca, 1997.

RodríGuez, N., El consenso en el proceso penal español, JMB, Barcelona, 1997.

Rosetт, A., "Discretion, Severity and Legality in Criminal Justice", en S. Cal. L. Rev., vol. 46, 1972-1973, pp. 12-50.

Roxin, C., Derecho Procesal Penal, Editores del Puerto, Buenos Aires, 2000, p. 89.

RuIz V., E., "El principio de oportunidad reglada", en AAVV, La Reforma del Proceso Penal. II Congreso de Derecho Procesal de Castilla y León, Ministerio de Justicia, Madrid, 1989, pp. 387-406.

Ruiz V., E., Estudios de Derecho procesal penal, Comares, Granada, 1995.

SAINZ M., F. Conceptos Jurídicos, interpretación y discrecionalidad administrativa, Civitas, Madrid, 1976. SÁnchez M., M., Discrecionalidad administrativa y control judicial, Tecnos, Madrid, 1994.

Serra D., M., Estudios de Derecho Procesal, Ariel, Barcelona, 1969.

Soтo P., M., "Ministerio Público y Política Criminal", en AAVV, El Ministerio Público para una nueva justicia criminal, Fundación Paz Ciudadana, Escuela de Derecho Universidad Diego Portales, Corporación de Promoción Universitaria, Santiago, 1994, pp. 135-157. 
Vives A., T.S., La reforma del proceso penal. Comentarios a la ley de medidas urgentes de reforma procesal II, Tirant lo Blanch, 1992.

Vorenberg, J., "Narrowing the Discretion of Criminal Justice Officials", en Duke L.J., vol. 1976, núm. 4, Sep. 1976, pp. 651-697.

Welzel, H., Derecho Penal Alemán, 4ª ed., Ed. Jurídica de Chile, Santiago, 1997.

ZaGrebelsky, V., "Independencia del ministerio público y obligatoriedad de la acción penal", en Revista de Ciencias Penales, No especial Ministerio Público, 1990-1993, pp. 112-136.

Zalaquett, J. y Nash, C., "Proceso Penal y Derechos Humanos", en Revista de derecho procesal, Depto. de Derecho Procesal, Facultad de Derecho, Universidad de Chile, núm. 20, 2005, pp. 61-97. 